\title{
درجة توفر معاييرضمان جودة البرامج الأكاديمية في كلية الشريعة والدراسات الإسلامية في جامعة القصيم من وجهة نظر أعضاء هيئة التدريس'
}

\author{
نائل محمد إبراهيم قرقز \\ أستاذ مناهج وطرق تدريس التربية الإسلامية المشارك في كلية الشريعة والدراسات الإسلامية- جامعة القصيم \\ dr.nail196833@gmail.com
}

الملتخص:

هدفت هذه الدراسة التعرف إلى درجة توفر معايير ضمان جودة البرامج الأكاديمية في كلية الشريعة والدراسـات الإسلامية في جامعة القصيم من وجهة نظر أعضاء هيئة التدريس. فقد تكونت العينة من جميع أفراد مجتمع الدراسة الأصلي والبالغ عددهم (YVV) عضو هيئة تدريس خلال

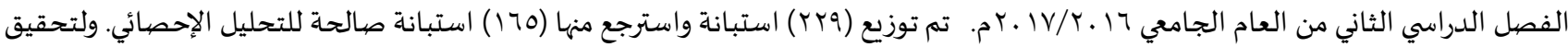
هدف الدراسـة تم تطوير استبانة مكونة من (r 9) فقرة موزعة على أحد عشر مجالاً. وقد أظهرت نتائج الدراسة أن درجة توفر معايير ضمان جودة

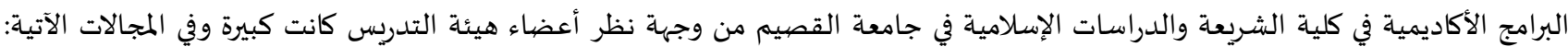

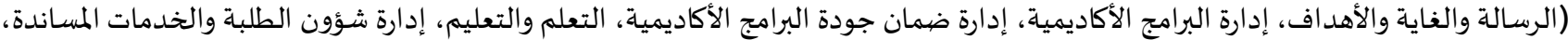

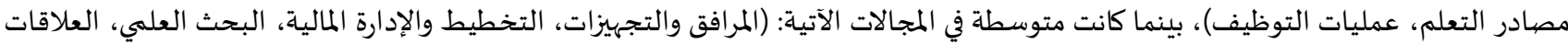

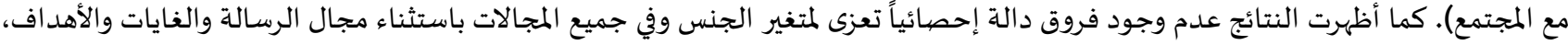

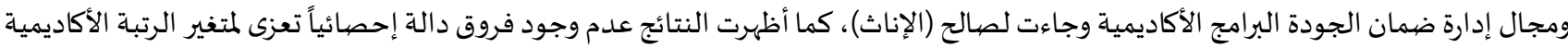

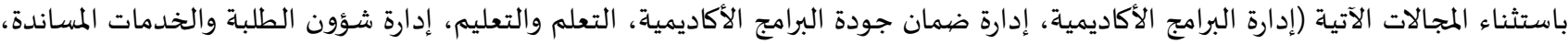
عمليات التوظيف) وجاءت لصالح (أستاذ مشارك، وأستاذ مساعد). وقد خرجت الدراسة بمجموعة من التوصيات أهمها: تطوير تطبيق المعايير التي حصلت على درجة متوسطة، إجراء دراسات مستقلة للمقارنة بين جودة البرامج الأكاديمية في كلية الشريعة والدراسات الإسلامية ومثليتها في الكليات

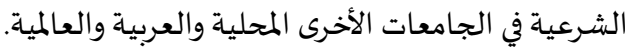

الكلمات المفتاحية: معايير ضمان الجودة، البرامج الأكاديمية، كلية الشريعة والدراسات الإسلامية، جامعة القصيم. (c) (7)

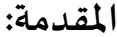

يعد التعليم العالي وسيلة لتقدم ورفاهية المجتمعات، ورقيها وتطورها؛ فالجامعات مؤسسات علمية، وتربوية ذات مستويات رفيعة، تتركز مهامها الرئيسة في إعداد الكوادر المؤهلة؛ لتبوء مراكز قيادية في مختلف المجالات الموجودة في المجتمع وإعداد البحوث النظرية والتطبيقية التي تتطلبها عملية التقدم العلمي والتكنولوجي في المجتمع، من أجل خدمته من خلال أنشطة علمية متعددة، ومختلفة لتكون على اتصال مستمر باه فيتحسن تطويره من خلالها.

تعد قضية ضمان الجودة للجامعات من القضايا المهمة والملحة في الوقت الحاضر وفي ظل ما فرضاه الواقع المعاصر والتوقعات المستقبلية

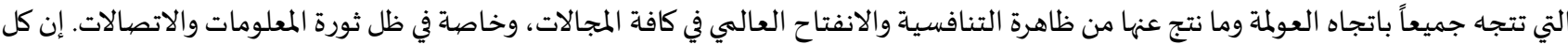

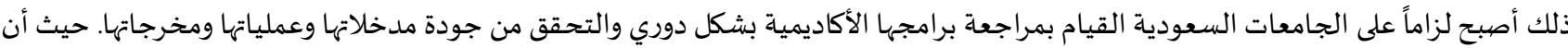

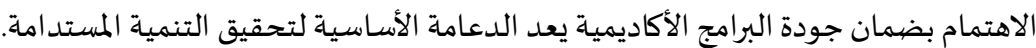

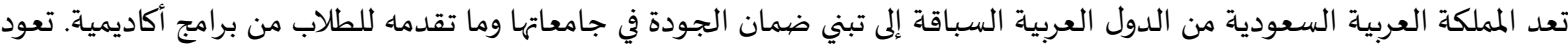

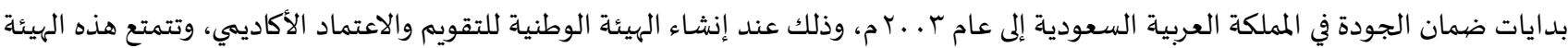
بالاستقلالية المالية والإدارية تحت إشراف مجلس التعليم العالي. وتعنى هذه الهيئة بمتابعة شؤون الاعتماد الأكاديمي في مؤسسات التعليم العالي فوق

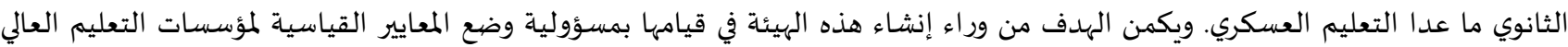
وبرامجها التعليمية كافة بما فهها برامج الدراسات العليا، ومن ثم تقويمها واعتمادها شريطة أن تستوفي معايير الجودة المطلوبة. وفي سبيل ذلك أصديدرت 
الهيئة دليل "معايير ضمان الجودة والاعتماد الأكاديمي في برامج مؤسسات التعليم العال"، وقد شملت المعايير التي وضعتها الهيئة الوطنية للتقويم

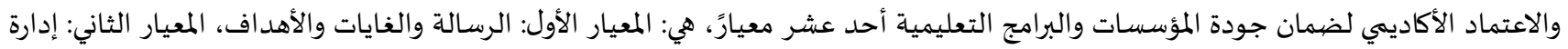
البرامج، المعيار الثالث: إدارة ضمان جودة البرامج، المعيار الرابع: التعلم والتعليم، المعيار الخامس: إدارة شؤون الطلبة والخدمات المساندة، المعيار

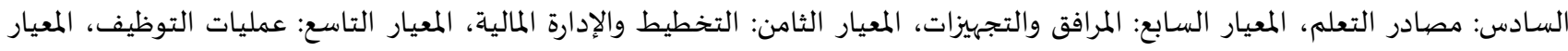
العاشر: البحث العلمي، المعيار الحادي عشر: العلاقات مع المجتمع (الهيئة الوطنية للتقويم والاعتماد الأكاديمي ، 11 . ب).

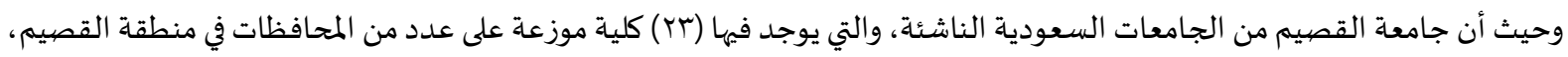

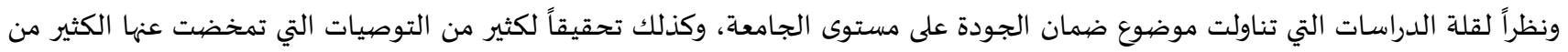

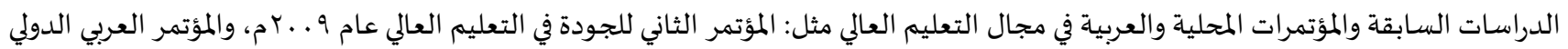

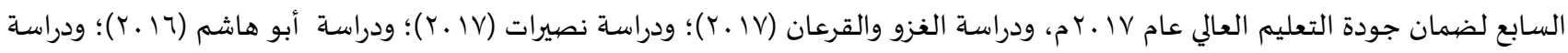

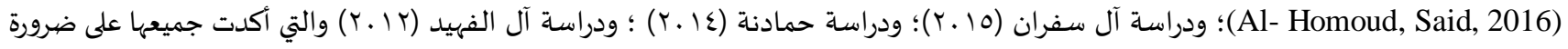

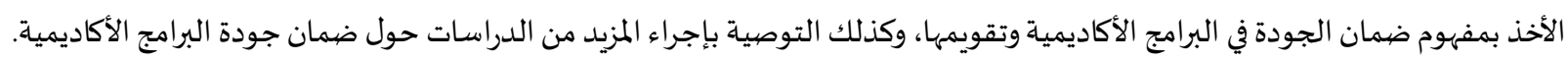

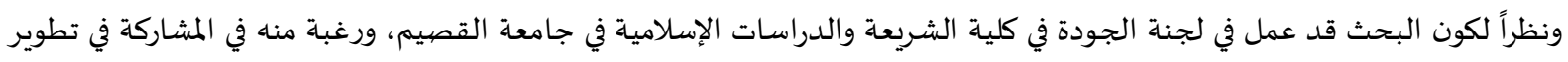

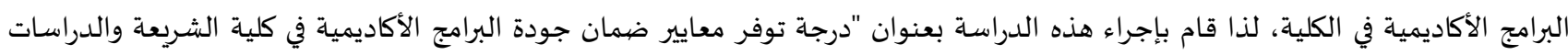
الإسلامية في جامعة القصيم من وجهة نظر أعضاء هيئة التدريس".

مشكلة الدراسـة وأسـئلتها

تتمثل مشكلة الدراسة الحالية في محاولتها الإجابة عن السؤالين الآتيين:

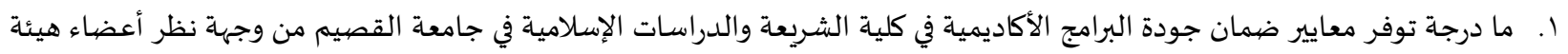
التدريس؟ مإد

r. هل توجد فروق دالة إحصائياً بين متوسطات استجابات أعضاء هيئة التدريس في تحديدهم لدرجة توفر معايير ضمان جودة البرامج

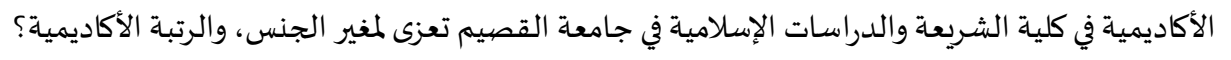

أهداف الدراسـة

تسعى الدراسة الحالية إلى تحقيق الأهداف التالية:

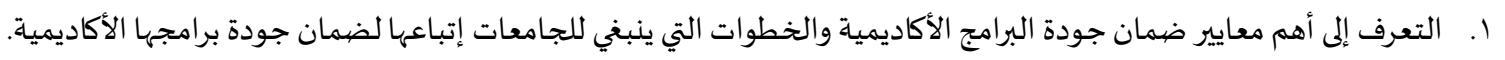

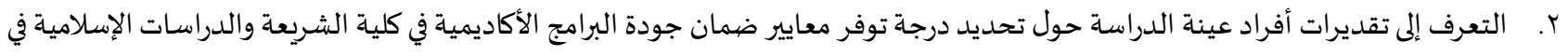
جامعة القصيم. r. تحديد الفروق بين استجابات أفراد عينة الدراسة حول درجة توفر معايير ضمان جودة البرامج الأكاديمية في كلية الشريعة والدراسات الإسلامية في جامعة القصيم تعزى لمتغير الجنس ، والرتبة الأكاديمية.

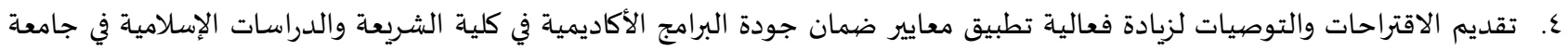
القصيم.

\section{أهمية الدراسة}

تستمد الدراسة الحالية أهميتها من خلال:

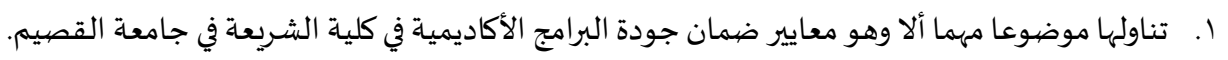

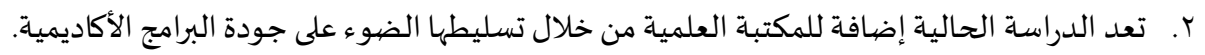

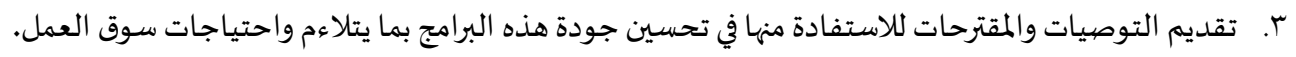

حدود الدراسـة

تقتصر حدود الدراسة الحالية وإمكانية تعميم نتائجها على الحدود الآتية:

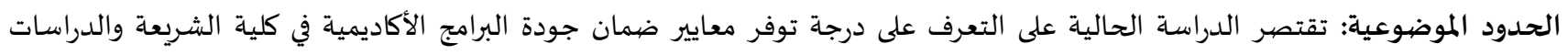

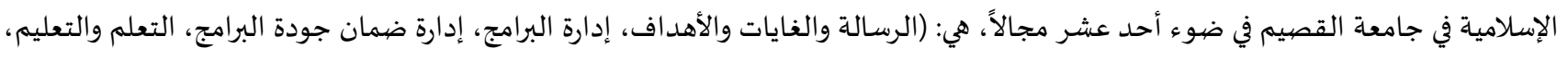


إدارة شؤون الطلبة والخدمات المساندة، مصادر التعلم، المرافق والتجهيزات، التخطيط والإدارة المالية، عمليات التوظيف، البحث العلمي، العلاقات مع المجتمع). الحدود المكانية: كلية الشريعة والدراسات الإسلامية في جامعة القصيم في المملكة العربية السعودياة.

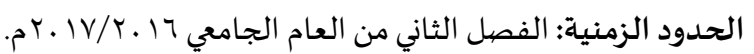
الحدود البشرية: أعضاء هيئة التدريس العاملين في كلية الشريعة والدراسات الإسلامية في جامعة القصيميم، وممن هم برتبة (أستاذ، أستاذ مشارك، أستاذ مسـاعد، محاضر، معيد). مصطلحات الدراسـة اشتملت الدراسة الحالية على المصطلحات التالية: درجة توفر: هي الدرجة الكلية التي يتم الحصول عليها من استجابات عينة الدراسة حول فقرات الاستبانة التي أعدت لهذا الغرض.

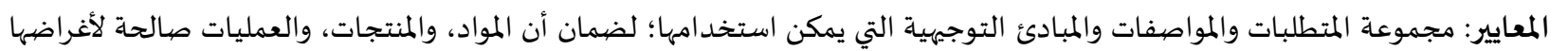

(ISO, 2017)

معايير ضمان الجودة: هي مجموعة المواصفات اللازمة للتعليم العالي والجامعي الجيد الذي يمكن قبوله؛ لضمان جودته، وزيادة فعاليته على

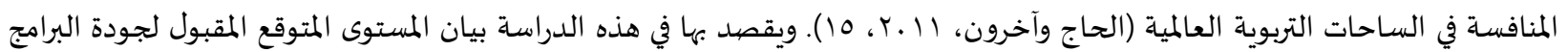
الأكاديمية في كلية الشريعة والدراسات الإسلامية في جامعة القصيم، والذي قررته الجهة المانحة للاعتماد بشأن درجة أو ناتج معين، يراد الوصول إليه ولا يقل عن الحد الأدنى للمعيار القياسي.

هالبرامج الأكاديمية: يقصد بها في هذه الدراسة جميع البرامج الأكاديمية في جامعة القصيم في التخصصيات الشرعية. جامعة القصيم: هي جامعة سعودية عامة، موقعها في منطقة القصيم تمنح درجة البكالوريوس والدبلوم والماجستير والدكتوراه وفق الدراسة

المنتظمة.

$$
\begin{aligned}
& \text { الأدب النظري والدراسـات السـابقة } \\
& \text { أولاً: الأدب النظري } \\
& \text { مفهوم ضمان جودة البرامج الأكاديمية }
\end{aligned}
$$

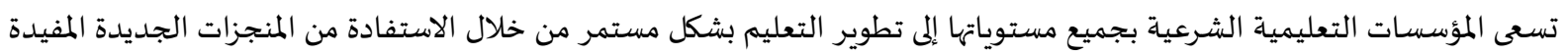

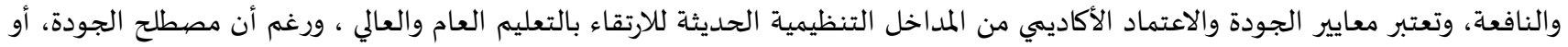

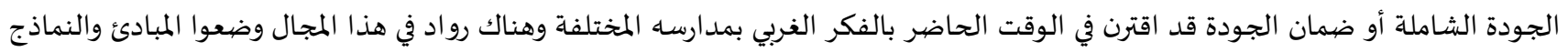

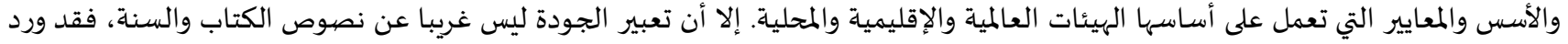

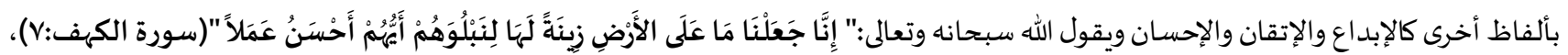

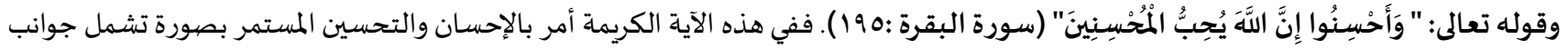

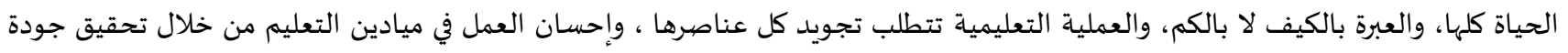

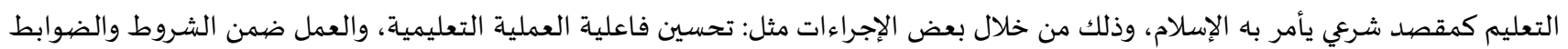
والمعايير المحددة من قبل مؤسسات وهيئات محلية وإقليمية ودولية، بهدف تقليل الأخطاء، والخروج بنواتج تعليمية يتوفر فهها الإحسان والإتقان كما

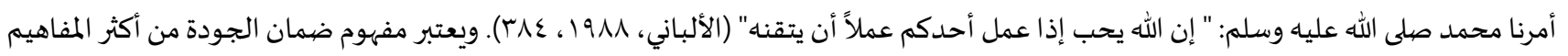

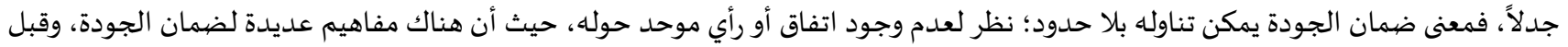

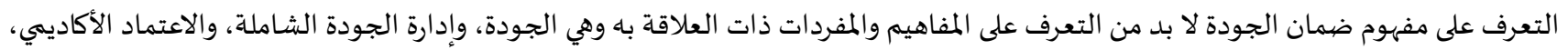
ومن ثم تعريف ضممان الجودة.

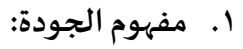

تعود كلمة الجودة في اللغة العربية إلى الفعل جود، وهي تعني نقيض الرديء، وجاد الشيء جُودة وجَودة أي صار جيداً، وأجدت الشيء فجاد

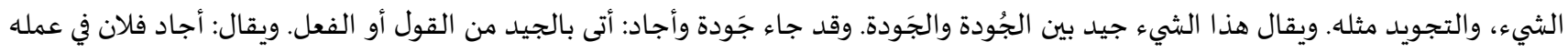

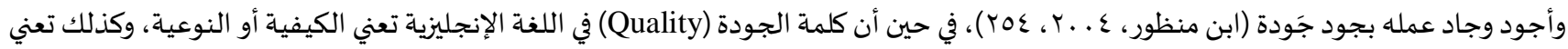


الامتياز، وأحيانا تعني تلك العلامات أو المؤشرات التي يمكن من خلالها تحديد الشيء أوفهم بنيته (مجيد والزيادات، م . .ب)، وكذلك تعني مجموعة من

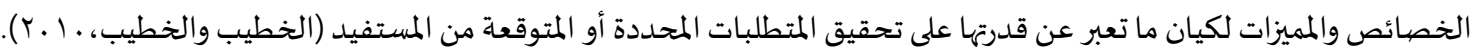

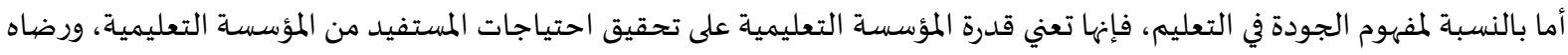

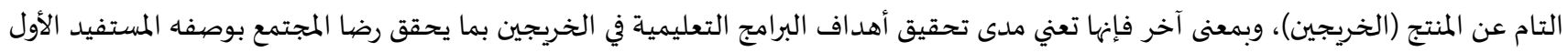

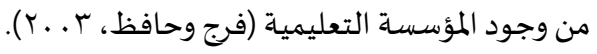

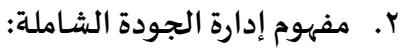

تعرف إدارة الجودة الشاملة بأها مجموعاة المبادئ والسياسات والهياكل التنظيمية المتميزة باستخدام كافة الموارد المادية والبشرية المتاحة،

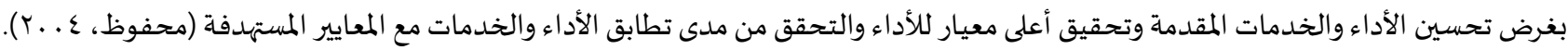

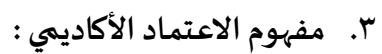

يعرف الاعتماد بأنه عملية مراجعة للجودة الخارجية، تستخدم بواسطة التعليم العالي لمراقبة الكليات والجامعات والبرامج الأكاديمية

لضيمان الجودة وتحسينها (CHEA,2017).

ع. مفهوم ضمان الجودة:

يعرف مصطلح ضمان الجودة بأنه تأدية العمل الصحيح على نحو صحيح من المرة الأولى مع الاعتماد على الاستفادة بتقويم المستفيد في

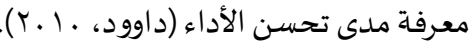

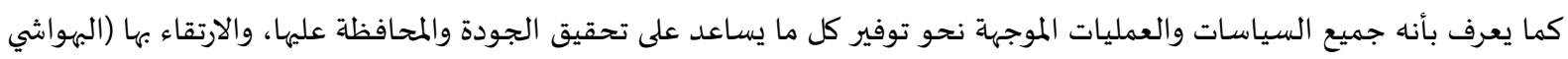

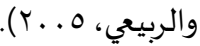

أما بالنسبة لضمان الجودة في التعليم، فإنه يعرف بأنه مجموعة من الأنشطة والإجراءات والمعايير المستخدمة في فحص وتقييم المؤسسات التعليمية والدراسية؛ للتحقق من استيفاء الشروط والمقومات الأكاديمية والتنظيمية والإدارية التي تضمن تحقيق رؤية ورسالة وأهداف هذهاءه المؤسسات في مجالات التعليم والتعلم والبحوث وتطوير المعرفة وخدمة المجتمع، بشكل يتلاءم مع تلك المستويات المتعارف عليها عالميا (مخيمر، 0. . ب).

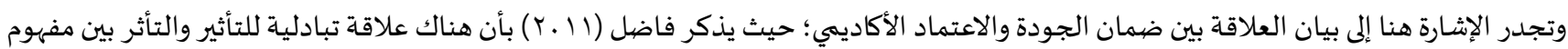

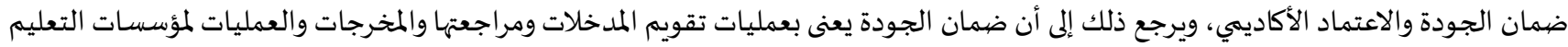

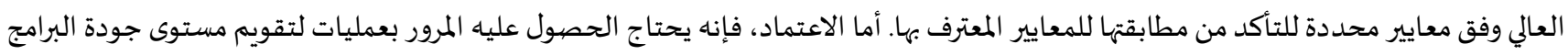

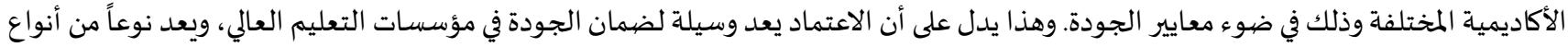

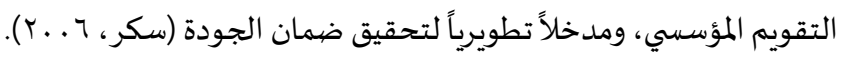
أهداف ضمان جودة البرامج الأكاديمية

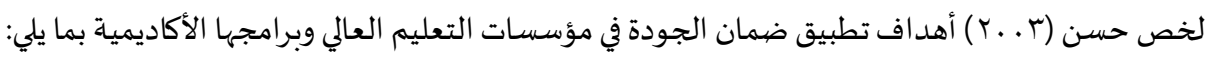

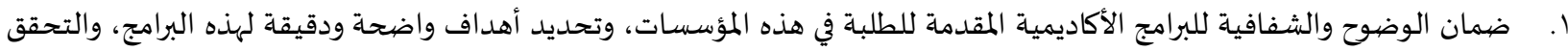

من توفر الشروط اللازمة لتحقيق هذه الأهداف بفاعلية من خلال توفير آلية لمساءلة جميع المعنيين بالإعداد والتنفيذ والإشراف عليها.

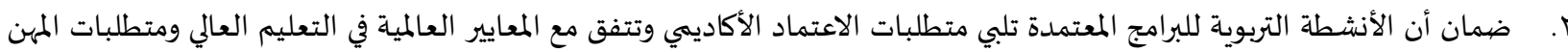

وكذلك حاجات الجامعات، والطلبة، والدولة، والمجتمع.

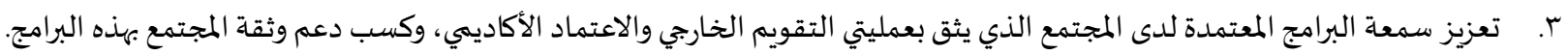

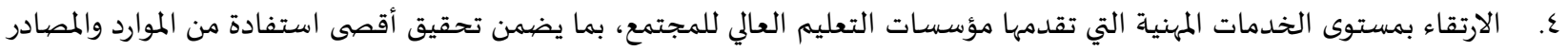

وصولا إلى مخرجات تعليمية عالية الجودة. بهون.

0. الاستعداد لعملية الاعتماد البرامجي أو التخصصي (BezuidenhoL \& Venter, 2007).

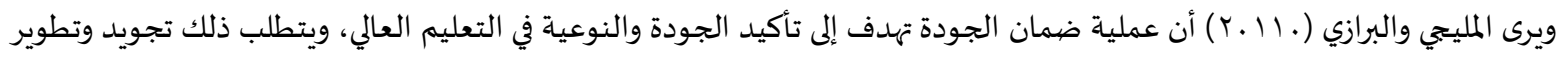

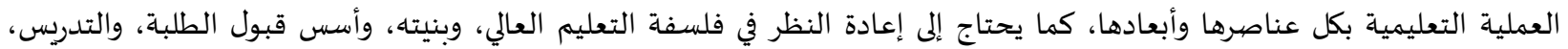

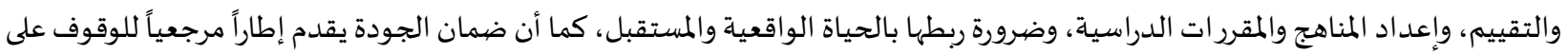
الروابط بين البرامج الأكاديمية، والأجهزة الأكاديمية والإدارية لمؤسسات التعليم العالي، حيث تؤدي ضمانمان الجودة إلى تحسئ تحسين فعالية نظم التعليم، وفي الوقت نفسـه فإن وجود تقييم خارجي لتقييم فاعلية الإدارة الجامعية، سيزيد من كفاءة مؤسسات التعليم العالي وفعاليتها. 
معايير ضمان جوة البرامج الأكاديمية

تعد معايير ضمان جودة البرامج الأكاديمية متطلبات الحد الأدنى من معايير الجودة التي يشترط للبرامج الأكاديمية استيفاؤها من أجل

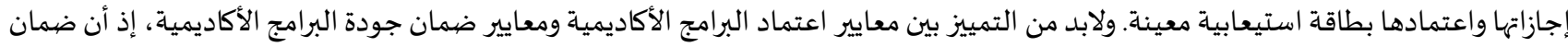

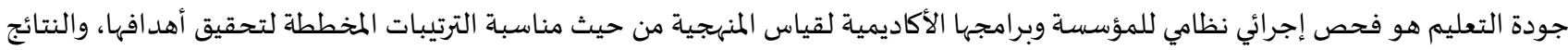

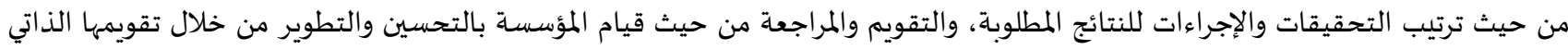

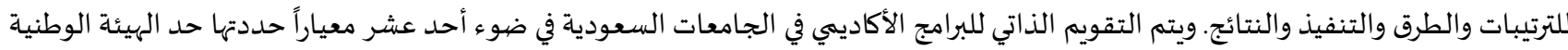

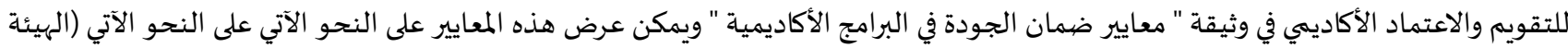

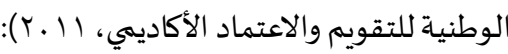
المعيار الأول: الرسالة والغايات والأهداف (يجب أن تكون رسالة البرنامج متسقة مع رسالة المؤسسة وتادئة وتدعم تطبيقها على غايات ومتطلبات البرنامج،

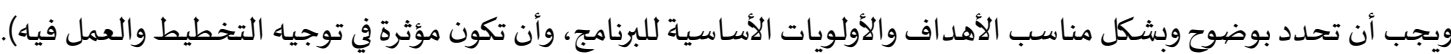

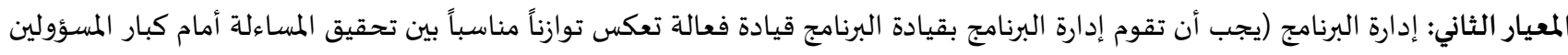

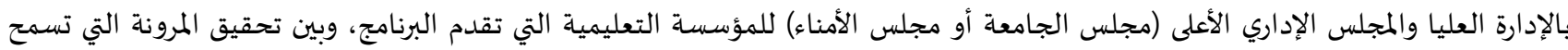

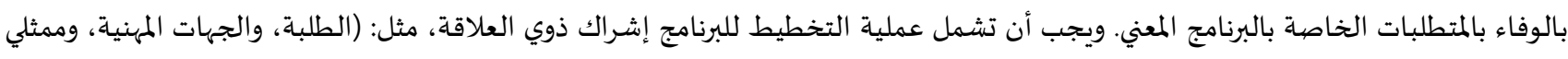

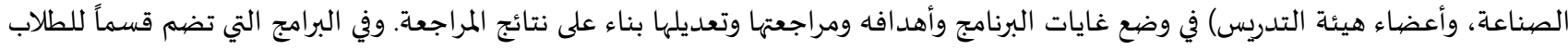

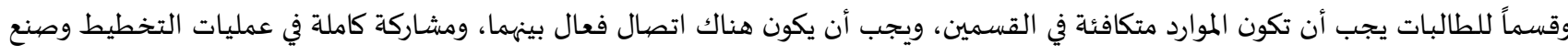
القرار في كل منهما. ويجب أن تكون هناك مراقبة دورية لجودة المقررات وجودة البرنامج، وأن تجرى التعديلات اللازمة بناءً على التغذية الراجعة من فئن

عملية التقويم، والتطورات في البيئة الخارجية التي تؤثر على البرنامج).

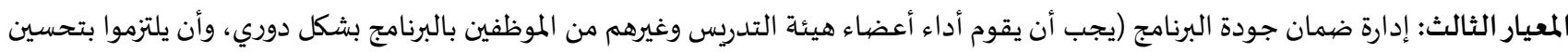

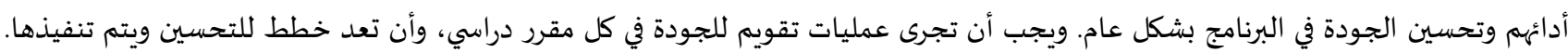

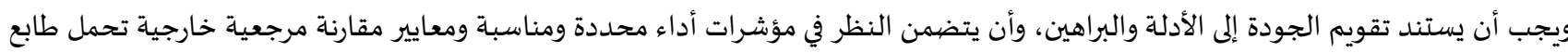

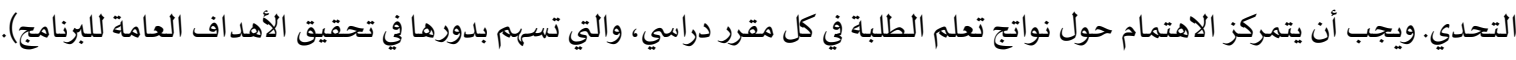

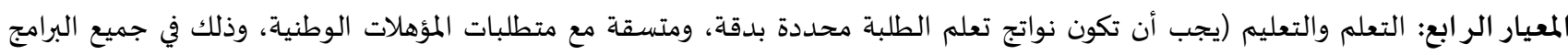

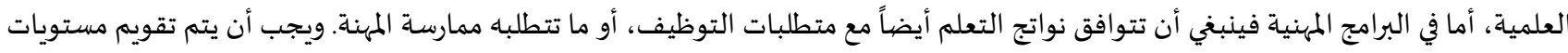

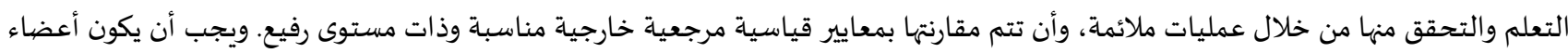
هيئة التدريس مؤهلين بصورة مناسبة، ولديهم الخبرة اللازمة للقيام بمسؤولياتهم التدريسية، وأن يطبقوا استراتيجيات تدريسية ملائمة للنواتج

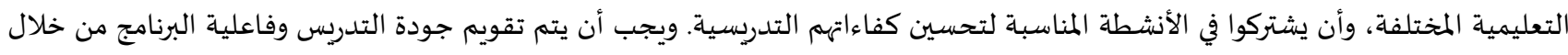

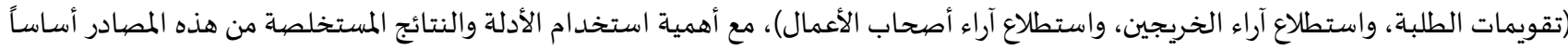

لخطط التحسين. ويجب أن تكون المستويات المطلوبة في أقسام الطلاب وأقسام الطالبات متماثلة، ولا بد من توفير الموارد بشكل متكافئ في الشطرين).

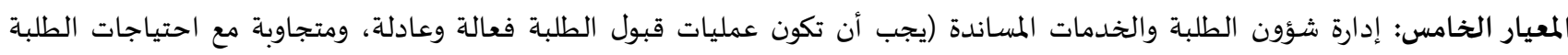

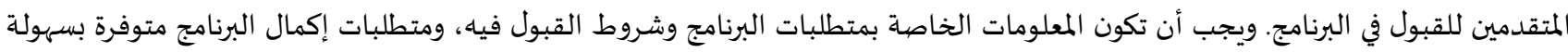

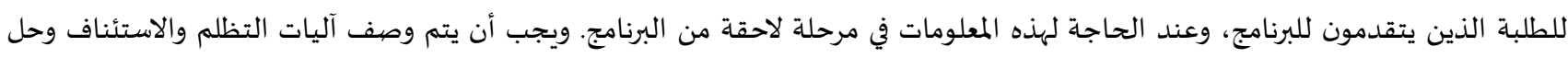

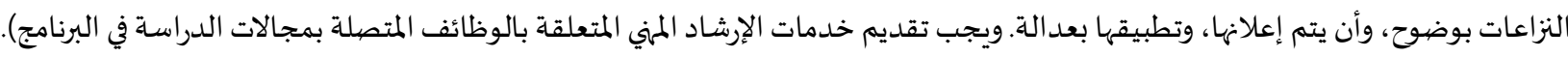

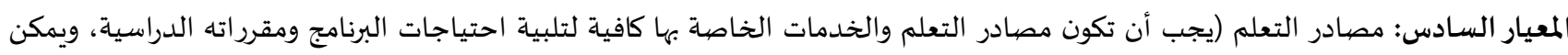

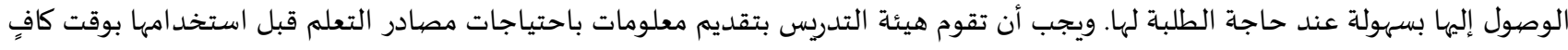

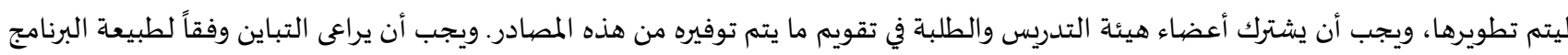

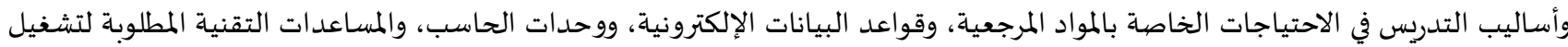

هذه التجهيزات).

المعيار السابع: المرافق والتجهيزات (يجب توفر مرافق وتجهيزات مناسبة للوفاء باحتياجات التعلم والتعليم في البرنامج. ويجب أن تتم متابعة مدى

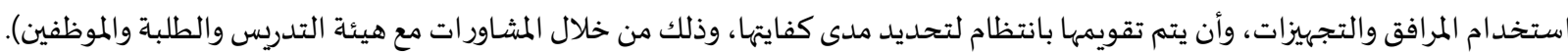


المعيار الثامن: التخطيط والإدارة المالية (يجب أن تكون الموارد المالية كافية لضمان تقديم البرنامج بفعالية. ويجب أن تكون متطلبات البرنامج معروفة

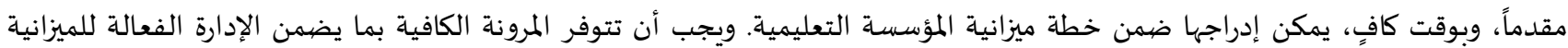
والاستجابة للأحداث غير المتوقعة، ويتب أن تكون تلك المرونة مصحوبة بدرجة مناسبة من المساءلة وآليات تقويم التقارير). المعيار التاسع: عمليات التوظيف (يجب أن يكون لدى هيئة التدريس وغيرهم من الموظفين في البرنامج المؤهلات والخبرات اللازمة للقيام بمهامهم الميه التدريسية ومسؤولياتهم الأخرى، ويجب التحقق من تلك المؤهلات والخبرات قبل التعيين. ويجب أن يعطى أعضاء هيئة التدريس الجدد فكرة واضحة

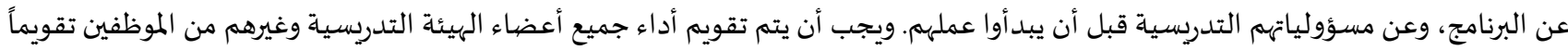
دورياً، وأن يتم تقدير الأداء المتميز، مع تقديم وعن الدعم للتنمية المهنية وتطوير الأداء التدريسي لأعضياء هيئة التدريس).

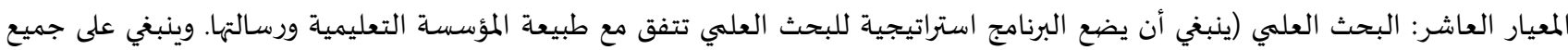

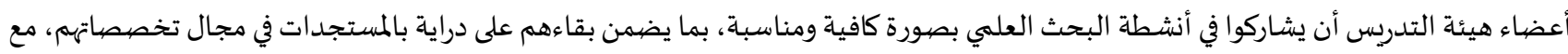

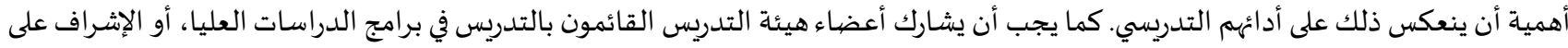
أبحاث طلبة الدراسات العليا، مشاركة نشطة في البحث العلمي في مجالات تخصصياتهم. ويجب أيضاً أن تتوافر المرافق والتجهيزات اللازمة لدعم أنسات أنشطة البحوث الخاصة بأعضاء هيئة التدريس وطلبة الدراسات العليا؛ للوفاء بهذه المتطلبات في المجالات ذات العلاقة بالبرنامج. ويجب أن تقدر الإنجازات

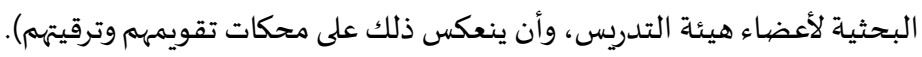

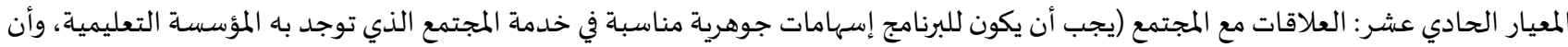

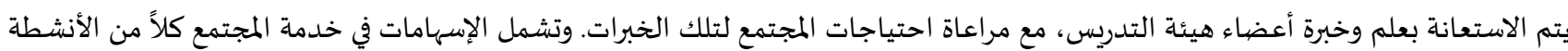
التي ينفذها منسوبو البرنامج، والتي تأتي نتيجة مبادرات منهم، إضافة إلى البرامج الرسمية التي تنظمها المؤسسة التعليمية أو المسؤولون عن إدهاءة إدارة

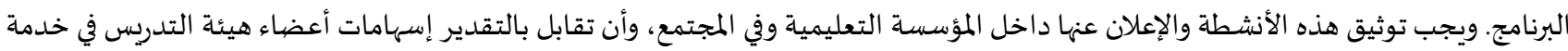
المجتمع (1)

متطلبات تطبيق ضيمان الجودة في البرامج الأكاديمية

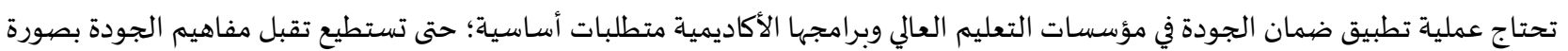
سليمة قابلة للتطبيق العملي وليس مجرد مفاهيم نظرية بعيدة عن الواقع، ولكي تترجم مفاهيم الجودة في مؤسسات التعليم العالي وبرامجها الأكاديمية للوصول إلى رضا المستفيد من المؤسسة. وهذه المتطلبات (مجيد والزيادات، م . . ب):

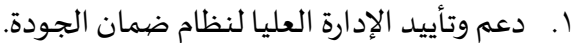

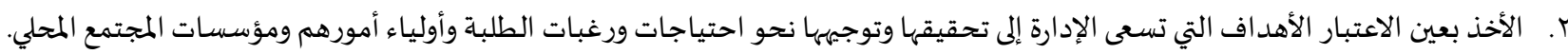
r. المشاركة جميع العاملين في المؤسسة.

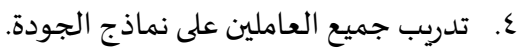

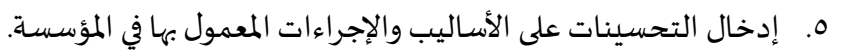
7. -تطوير المنهاج الدراسية وأساليب التقويه. V. ت توفير قاعدة للبيانات والمعلومات لاستخد امها في عملية اتخاذ القرارات. 1. تشجيع العاملين ومنحهم الثقاة والسلطة لأداء الأدوار والمهام المطلوبة منهم. 9. الاستفادة من التجارب في مؤسسات تعليم العالي المماثلة.

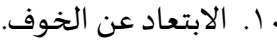

مراحل الحصبول على شهادة ضيمان الجودة للبرامج الأكاديمية

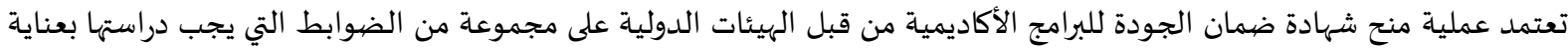

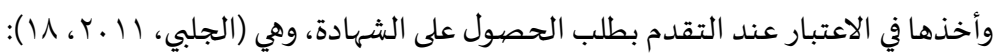

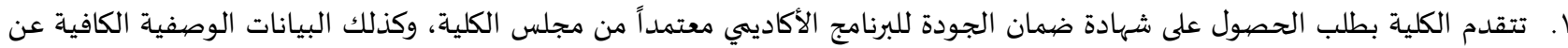

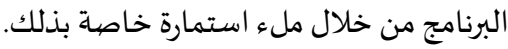

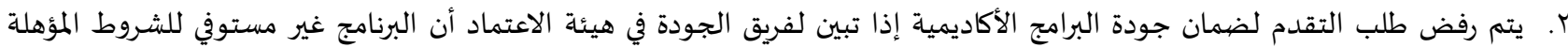

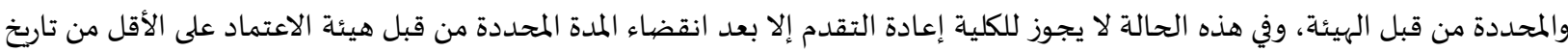
رفض الطلب. 


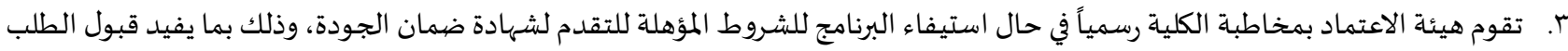

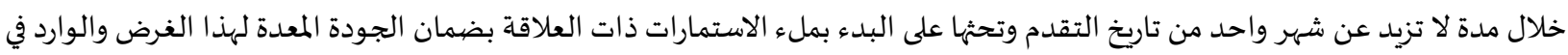

$$
\text { دليل ضمان جودة البرامج الأكاديمياة. }
$$

ع. ـ يتعين على الكلية أن تدفع رسوم ضمان جودة البمان البرامج الأكاديمية والمحددة من قبل هيئة الاعتماد.

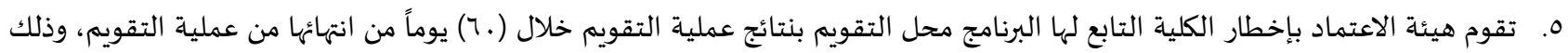

بكتاب موصى عليه متضمناً إحدى الحالات الآتية:

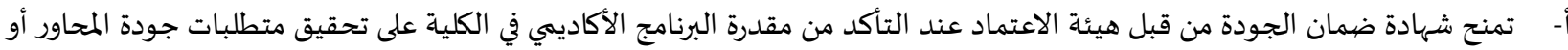

المعايير للبرنامج الأكاديمي. وتقوم الهيئة بالإعلان عن هذا المنح بإضافة اسم البرنامج والمؤسسة التابعة إلى سجل البرامج المعتمدة بسجلات

الهيئة وبموقعها الإلكتروني.

ب- تحجب شهادة ضمان الجودة عن البرنامج الأكاديمي في حالة عدم مقدرته على تحقيق بعض المعايير الخاصة بجودة البرنامج الأكاديمي،

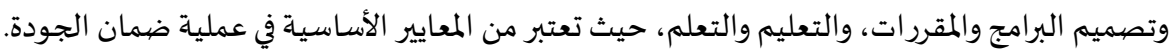

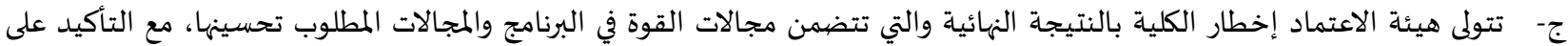

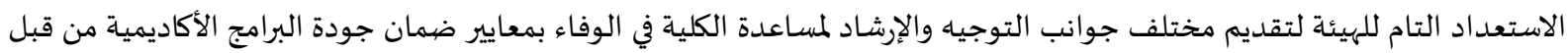

$$
\text { الهيئة. }
$$

\section{معوقات تطبيق ضمان الجودة في البرامج الأكاديمية}

تواجه عملية تطبيق ضمان الجودة في مؤسسات التعليم العالي مجموعة من المعوقات، أهمها (رقاد ولعكيكزة، 17 ــ ) :

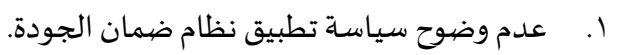

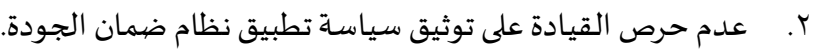
r. عدم حرص القيادة على التواصل مع هيئات الاعتماد المسؤولة عن التأكد من تحقيق ضمانمان الجودة في مؤسسـات التعليم العالي.

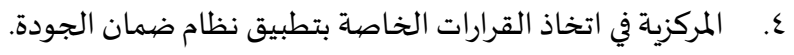
0. عدم قناعة القيادة بأهمية تطبيق نظام ضهمان الجودة.

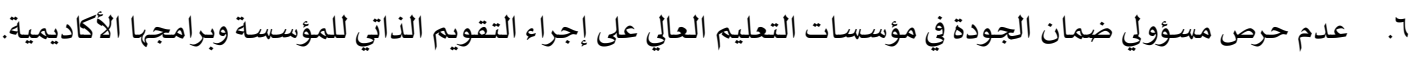

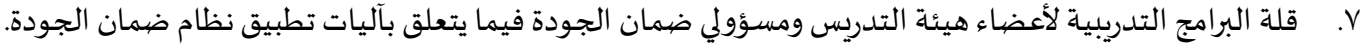

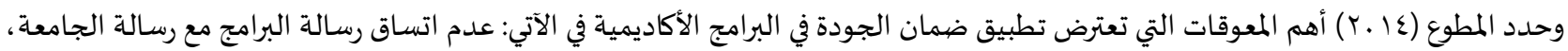
وعدم إجراء عملية التقويم لعناصر الجامعة بصورة دورياة، وعدم وجود إدارة لعمليات ضمان الجودة، وعدم مناسبة عمليات تقويم معايير التعلم، وقلة الدعم المخصص لتحسين جودة التدريس.

ثانياً: الدراسات السابقة

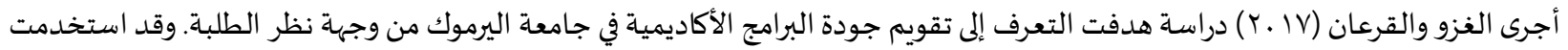
الدراسة المنهج الوصفي التحليلي. تكون مجتمع الدراسة من جميع طلبة البكالوريوس من مستوع الستوان السنة الثالثة والرابعة في جميع الكليات

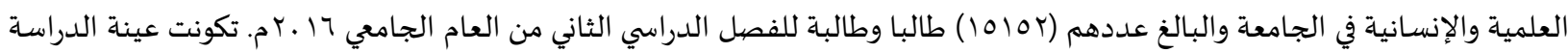

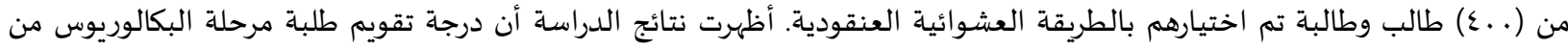

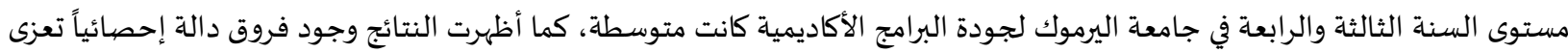
لمتغير الكلية. أجرى نصيرات (7) ـ إ) دراسة هدفت إلى مدى توافر معايير جودة البرنامج الأكاديمي في برنامج إعداد معلمي الموسيقى في الجامعة الأردنية من

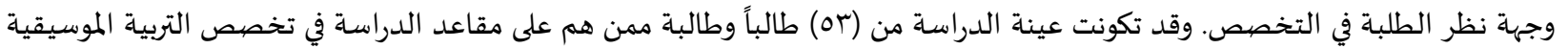
والأداء الموسيقي. اتبعت الدراسة المنهج الوصفي التحليلي. ولتحقيق هدف الدراسة تم استخدام استبانة مكونة من (7) مجالات. وقد أظهرت

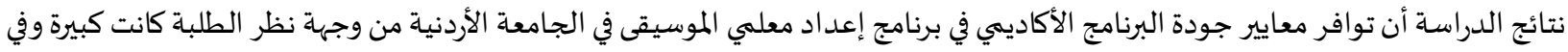
جميع المجالات الآتية (أهداف برنامج البكالوريوس، والمنهاج، وطرق التدريس، والتقويم، والجانب التطبيقي الميداني)، وكانت متوسطة في مجال

(المرافق والتجهيزات العينية). 
وهدفت دراسة قرقز (Y ( ا إلى التعرف على درجة تطبيق معيار جودة التعلم والتعليم في برامج كلية الشريعة والدراسات الإسلامية في جامعة

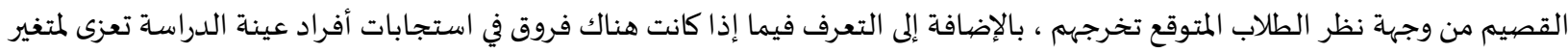

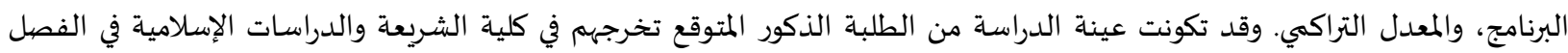

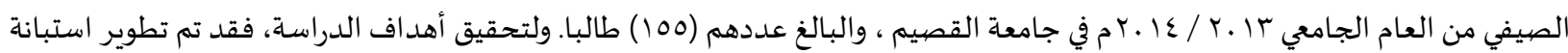

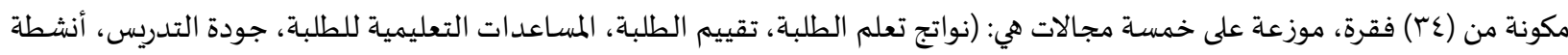

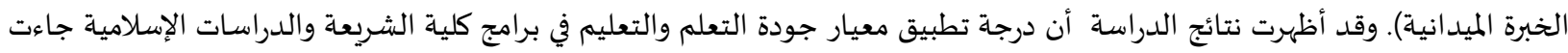

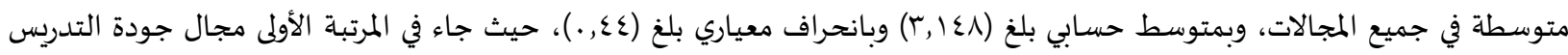

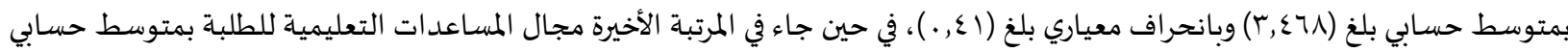

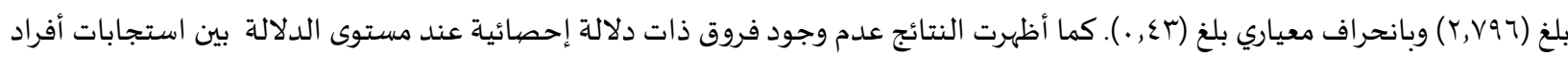
عينة الدراسـة تعزى لمتغير البرنامج، بينما أظهرت النتائج وجود فروق ذات دلاتلاتلة إحصائية تعزى لمتغير المعدل التراكمي لصالح (جيد جدا فأعلى).

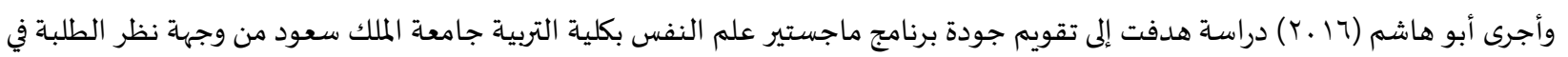

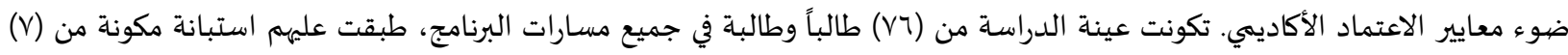

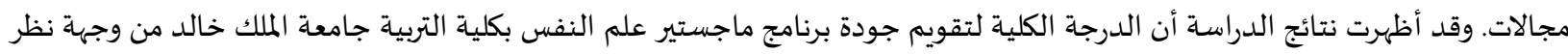

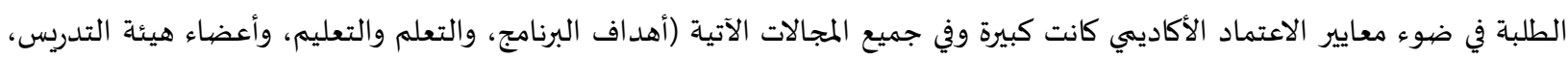
والقبول والتسجيل، والمرافق والتجهيزات)، ومتوسطة في مجالي (المقرر ات الدراسية، والإشراف). قامت العزام وعليمات (7 ا ـ ب) بدراسة بهدف التعرف إلى مستوى تطبيق معايير هيئة الاعتماد للبرامج التربوية في الدراسات العليا في كليات التربية الجامعات الأردنية الحكومية. اتبعت الدراسة المنهج الوصفي التحليلي. ولتحقيق ذلك تم تصميم استبانة وفق معايير هيئة الاعتماد للبرامج

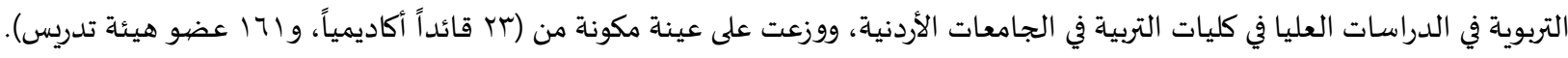

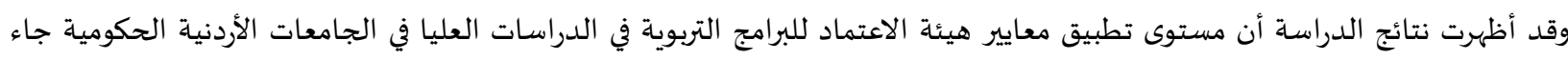

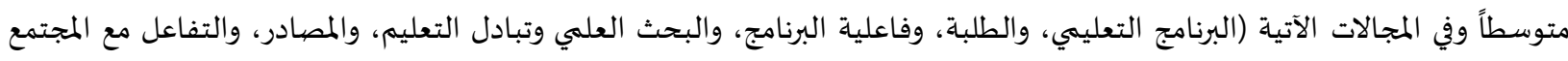

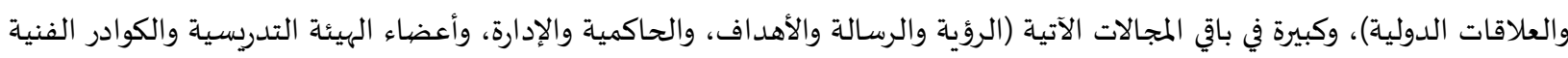

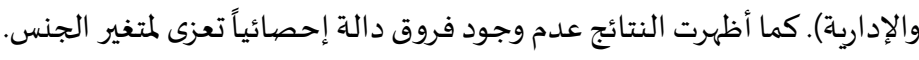

وقام) بداراسة هدفت للتعرف على تقويم جودة برامج الهندسة والإدارة الصناعية في جامعة الملك فهد للبترول والمعادن. وقد أظهرت نتائج الدراسة أن تقويم جودة برامج الهندسة والإدارة الصناعية في جامعة الملك فهد للبترول والمعادن تتطلب ألمادئ اتجاهات

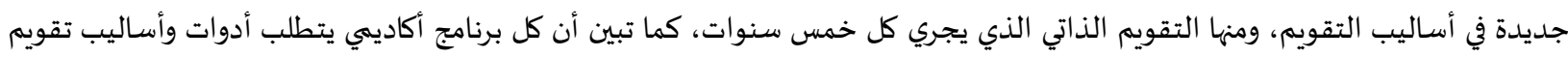

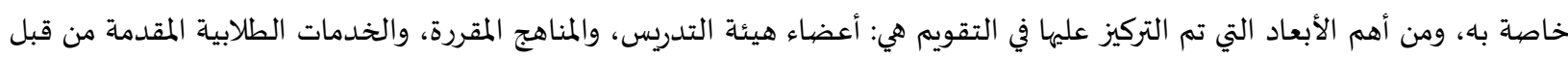

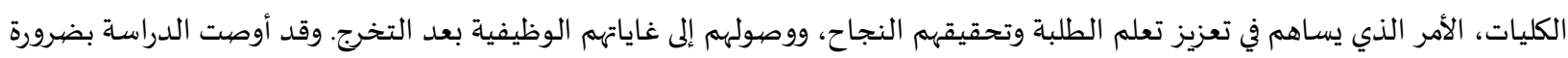
وجود فهم مشترك لرسالة البرامج الأكاديمية وأهد افها ونتائجها، وضرورة بذل الجهود من أجل تحسين جودة تلعيم تقويم البرامج الأكاديمية.

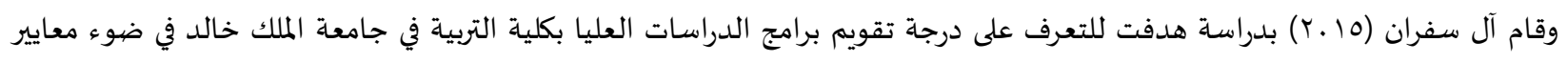

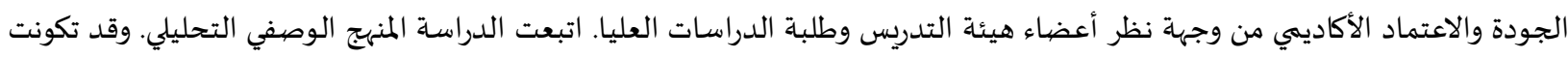

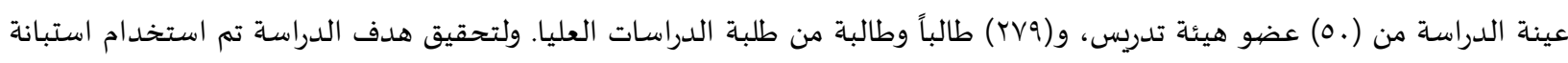

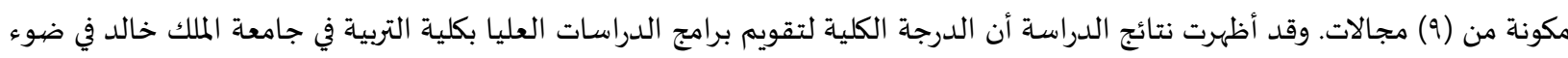
معايير الجودة والاعتماد الأكاديمي كانت متوسطة وكذلك في جمئ الاتهي المجالات الآتية (اللوائح والنظم التعليمية، والتعليم والتعلم، وتقويم تعلم

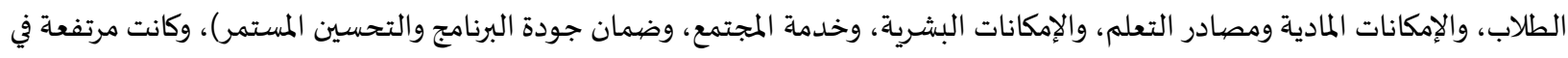

المجالين الآتيين (مواصفات البرنامج التعليمي، وإدارة البرنامج).

هدفت الدراسة التي أجراها حمادنة (عا • ا) للتعرف إلى درجة تطبيق معايير ضمان الجودة في برامج الدراسات العليا في كليات التربية في

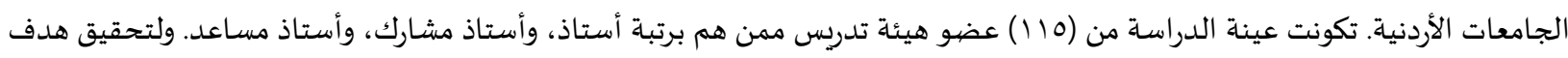

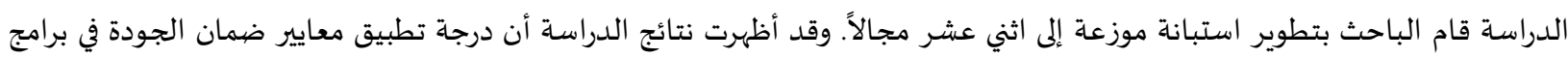

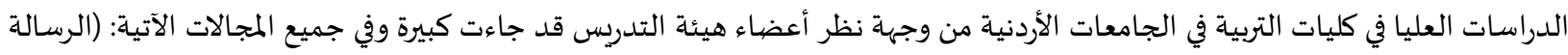

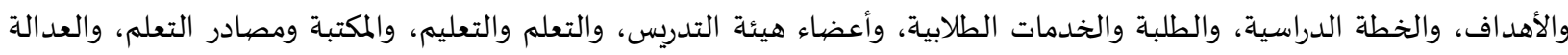

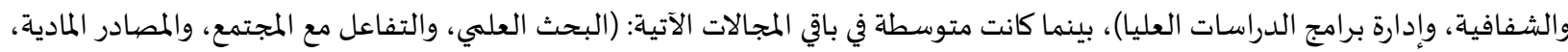


وإدارة ضمان جودة برامج الدراسات العليا). كما أظهرت النتائج وجود فروق دالة إحصائياً تعزى لمتغير الجنس، وكذلك تعزى لمتغير الرتبة الأكاديمية.

وهدفت الدراسة التي أجرتها آل الفهيد (Y ا ـr) إلى التعرف على درجة توفر معايير الاعتماد الأكاديمي في برامج الدراسات العليا التربوية بجامعة

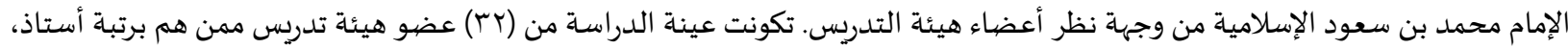

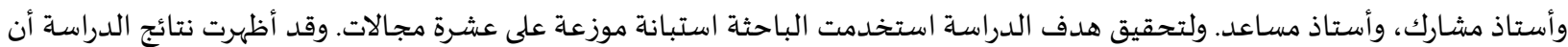

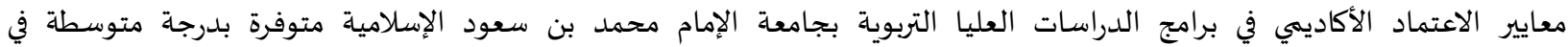

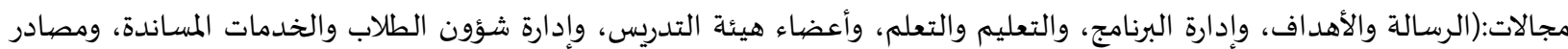

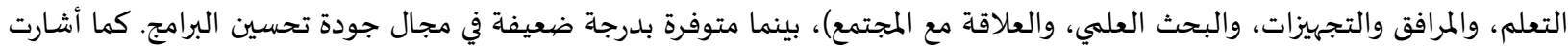

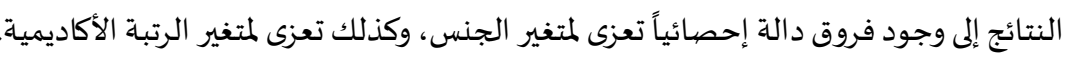
وأجرت (Elzubeir \& Al-Subait, 2012) دراسة بهدف التعرف إلى درجة تطبيق معايير الجودة في برنامج ماجستير التعليم الطبي في جامعة

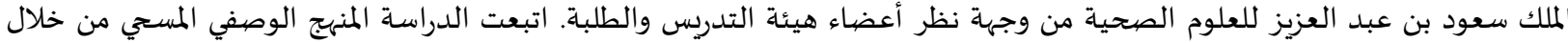

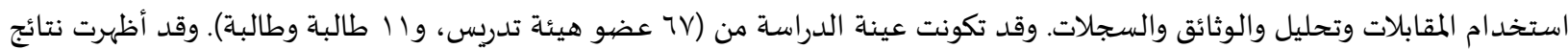
الدراسة أن درجة تطبيق معايير الجودة في برنامج ماجستير التعليم الطبي في جامعة الملك سعود بن عبد العزيز من وجهة نظر أعضاء هيئة

التدريس والطلبة كانت مرتفعة.

وفي دراسة قامت بها أبو دقة (و . (Y) بهدف التعرف إلى تقويم جودة البرامج الأكاديمية في الجامعة الإسلامية بغزة من وجهة نظر الخريجين.

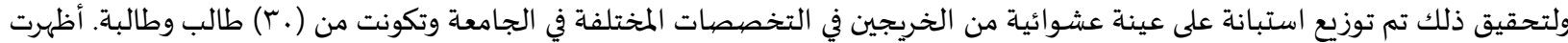

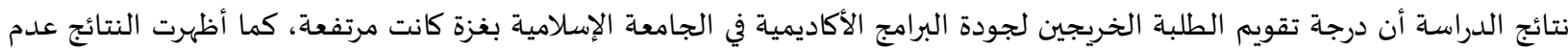
وجود فروق دالة إحصائيا تعزى لمتغير الجنس.

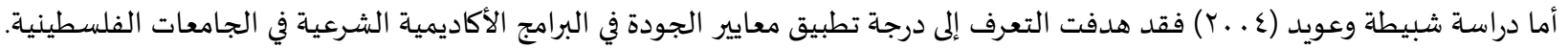
اتبعت الدراسة المنهج الوصفي التحليلي. وتكونت عينة الدراسة من (rع) عضو هيئة تدريس العاملين في كليات الشريعة والدراسات الإسلامية في

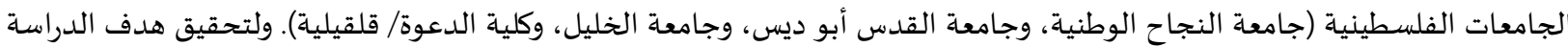

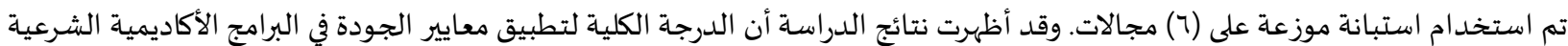

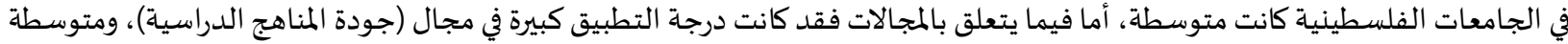

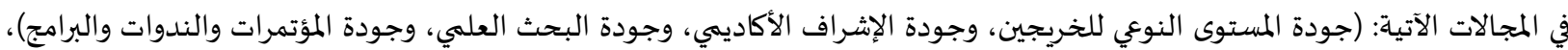
وقليلة في مجال (جودة الكتب والمؤلفات الدينية). تعقيب على الدراسات السابقة

يتضح من خلال استعراض الدراسات السابقة التالي:

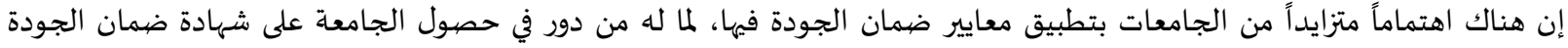

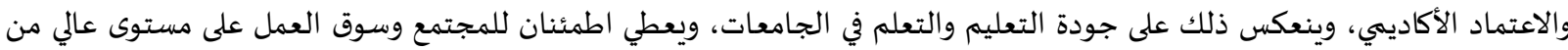
المهارات لخريجي هذه الجامعة.

ت تتفق الدراسة الحالية مع الدراسات السابقة في تناولها موضوع معايير ضمان جودة في البرامج الأكاديمية وفي أداة الدراسة. • استفاد الباحث من الدراسات السابقة في تحديد مشكلة الدراساة، وتحديد المنهج المتبع، واستخدام الاستبانة أداة لتحقيق أهداف الدراسة،

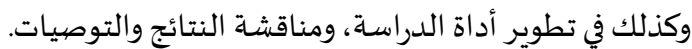
ت تختلف الدراسة الحالية عن الدراسات السابقة في محاولتها معرفة درجة توفر معايير ضمان جودة البرامج الأكاديمية في كلية الشريعة والدراسات الإسلامية في جامعة القصيم. منهجية الدراسة وإجراءاتها:

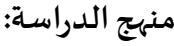
اعتمدت الدراسة على المنهج الوصفي التحليلي نظراً: لملائمته لطبيعة وأهداف الدراسة، وذلك باستخدام الاستبانة كأداة مسحية لجمع البيانات من أعضاء هيئة التدريس في كلية الشربعة والدراسات الإسلامية بجامعة القصييم. 
تكون مجتمع الدراسة من جميع أعضاء هيئة التدرس في كلية الشريعة والدراسات الإسلامية في جامعة القصيم في الفصل الأول للعام

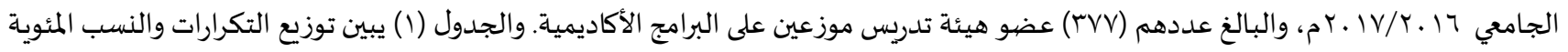
لأفراد مجتمع الدراسة حسب متغيرات الدراسة. جدول (1) : التكرارات والنسب المئوية لأفراد مجتمع الدراسة حسب متغيرات الدراسة

\begin{tabular}{|c|c|c|c|}
\hline النسب المئوية & التكرارات & الفئة & المتغير \\
\hline . VI & r79 & ذكور & \multirow[t]{2}{*}{ الجنس } \\
\hline -, 49 & 1.1 & إناث & \\
\hline . ז & $1 . \varepsilon$ & أستاذ مشارك فأعلى & \multirow{4}{*}{ الرتبة الأكاديمية } \\
\hline . זו & $1 \leq 0$ & أستاذ مساعد & \\
\hline . & $\varepsilon \wedge$ & محاضر & \\
\hline$\cdot, r)$ & $\wedge$. & معيد & \\
\hline $1 \ldots$, & rVv & & \\
\hline
\end{tabular}

عينة الدراسة:

نظراً لصغر حجم المجتمع فقد تكونت العينة من جميع أفراد مجتمع الدراسة الأصلي والبالغ عددهم (YVV) عضو هيئة تدريس. وفي الوقت

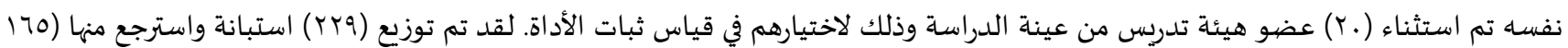

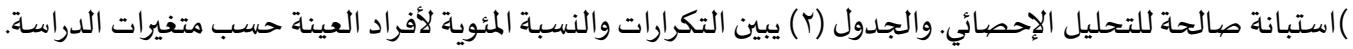

\begin{tabular}{|c|c|c|c|}
\hline النسب المئوية & التكرارات & الفئة & المتغير \\
\hline., 01 & 90 & ذكور & \multirow[t]{2}{*}{ الجنس } \\
\hline$\cdot, \varepsilon r$ & v. & إناث & \\
\hline$\cdot, \mathrm{r}$. & rt & أستاذ مشارك فأعلى & \multirow[t]{4}{*}{ الرتبة الأكاديمية } \\
\hline., 19 & 70 & أستاذ مساعد & \\
\hline$\cdot,{ }_{\Lambda}$ & $\varepsilon 7$ & محاضر & \\
\hline., $1 T$ & rr & معيد & \\
\hline $1 \ldots$, & 170 & \multicolumn{2}{|c|}{ المجموع } \\
\hline
\end{tabular}

أداة الدراسـة:

لتقدير درجة توفر معايير ضمان الجودة في البرامج الأكاديمية في كلية الشريعة والدراسات الإسلامية في جامعة القصيم من وجهة نظر

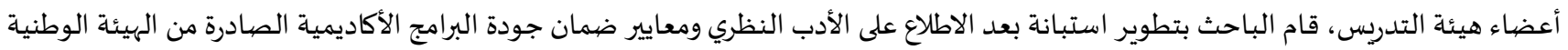

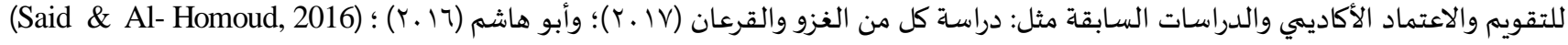

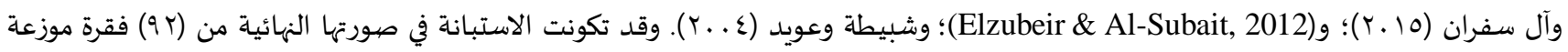
على أحد عشر مجالاً، هي: (الرسالة والغاية والأهداف، وإدارة البرامج الأكاديمية، وإدارة ضمان جودة البرامج الأكاديمية، والتعلم والتعليم، وإدارة شؤون الطلبة والخدمات المساندة، ومصادر التعلم، والمرافق والتجهيزات، والتخطيط والإدارة المالية، وعمليات التوظيف، والبحث العلمي، والعلاقدات جاتهات

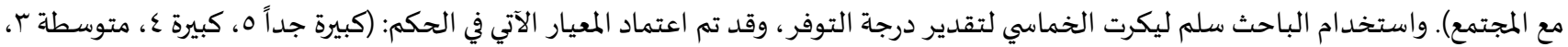

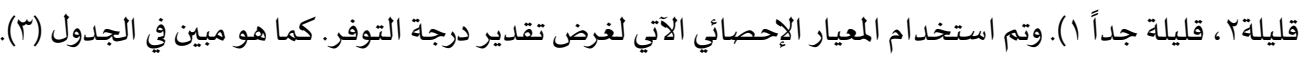
جدول (r): المعيار الإحصائي لتقديردرجة توفر معايير ضمان الجودة في البرامج الأكاديمية في كلية الشريعة والدراسات الإسلامية في جامعة القصيم من

\begin{tabular}{|c|c|c|}
\hline المستوى & 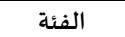 & م \\
\hline قليلة جداً & $1, \Lambda .-1, \ldots$ & 1 \\
\hline قليلة & $r, 7 .-1,11$ & r \\
\hline متوسطة & $r \varepsilon .-r, 7)$ & r \\
\hline كبيرة & $\{r .-r, \varepsilon 1$ & $\varepsilon$ \\
\hline كبيرة جداً & $0, \ldots-\varepsilon, r)$ & 0 \\
\hline
\end{tabular}


للتحقق من صدق أداة الدراسة، تم عرضها على مجموعة من المحكمين من أعضاء هيئة التدريس في كليتي الشريعة والدراسات

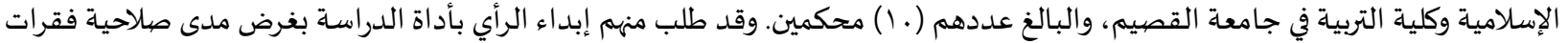

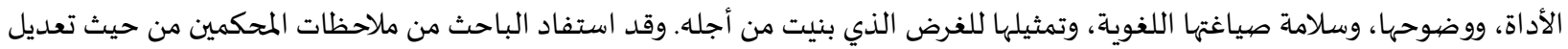

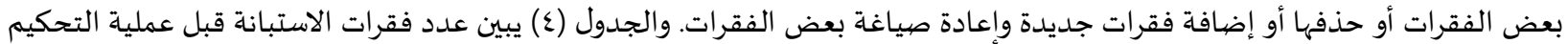

وبعدها.

\begin{tabular}{|c|c|c|c|c|c|}
\hline عدد الفقرات & عدد الفقرات & عدد الفقرات بعد & عدد الفقرات قبل التحكيم & المجال & الرقم \\
\hline . & 1 & 1. & 11 & الرسالة والغاية والأهداف & 1 \\
\hline . & . & 11 & 11 & إدارة البرامج الأكاديمية & r \\
\hline . & . & 7 & 7 & إدارة ضمان الجودة البرامج الأكاديمية & $r$ \\
\hline . & . & iv & iv & التعلم والتعليم & $\varepsilon$ \\
\hline . & 1 & 11 & IT & إدارة شؤون الطلبة والخدمات المساندة & 0 \\
\hline . & . & $\mathrm{V}$ & $\mathrm{v}$ & مصادر التعلم & 7 \\
\hline . & . & 0 & 0 & المرافق والتجهيزات & $\mathrm{v}$ \\
\hline . & $r$ & 0 & $\wedge$ & التخطيط والإدارة المالية & $\Lambda$ \\
\hline . & . & 0 & 7 & عمليات التوظيف & 9 \\
\hline 1 & 0 & 7 & 9 & البحث العلمي & 1. \\
\hline . & $r$ & 9 & 11 & العلاقات مع المجتمع & 11 \\
\hline 1 & Ir & 94 & $1 . r$ & المجموع & \\
\hline
\end{tabular}

ثبات أداة الدراسـة:

للتحقق من ثبات أداة الدراسة، تم اختيار عينة عشوائية استطلاعية من خارج عينة الدراسـة الأصلية، مكونة من (.ب) عضو هيئة

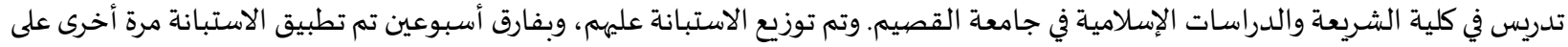
العينة الاستطلاعية. وبعدها تم حساب معامل ارتباط بيرسون بين التطبيقين، وبلغت قيمته للأداة (1، ر .)، كما تم حساب معامل ثبات الاتساق

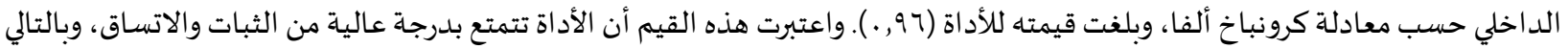

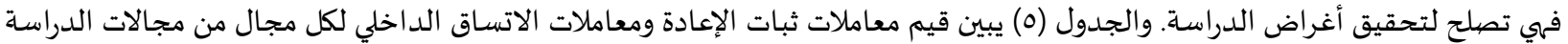

جدول (ه): قيم معاملات ثبات الإعادة والاتساق الداخلي لمجالات أداة الدراسة والأداة ككل

\begin{tabular}{|c|c|c|c|c|}
\hline معامل ثبات الاتساق الداخلي & معامل ارتباط بيرسون & عدد الفقرات & 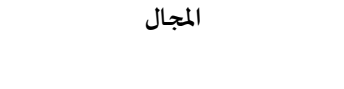 & 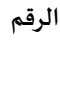 \\
\hline$\cdot, 91$ & $\cdot, 91$ & 1. & الرسالة والغاية والأهداف & 1 \\
\hline .,19 & . & 11 & إدارة البرامج الأكاديمية & $r$ \\
\hline .,AV & - & 7 & إدارة ضممان الجودة البرامج الأكاديمية & $r$ \\
\hline$\cdot, 9$. &., 19 & iv & التعلم والتعليم & $\varepsilon$ \\
\hline$\cdot, \Lambda$ & , 14 & 11 & إدارة شؤون الطلبة والخدمات المساندة & $\circ$ \\
\hline$\cdot, \wedge \varepsilon$ &., 9. & $\mathrm{v}$ & التعلم & 7 \\
\hline$\cdot, 9$. &., 17 & $\circ$ & المرافق والتجهيزات & v \\
\hline., 97 &.,$\Lambda \Gamma$ & $\circ$ & التخطيط والإدارة المالية & $\wedge$ \\
\hline$\cdot, 19$ & $\cdot, \mathrm{AV}$ & 0 & عمليات التوظيف & 9 \\
\hline$\cdot, \Lambda$ &., 9 & 7 & البحث العلمي & 1. \\
\hline$\cdot, \wedge \mathrm{V}$ &., 9 & 9 & العلاقات مع المجتمع & 11 \\
\hline$\cdot, 97$ & $\cdot, 19$ & $9 r$ & المجموع & \\
\hline
\end{tabular}


متغيرات الدراسة:

أولاً: المتغيرات المستقلة:

الجنس: (ذكر، أنثى).

الرتبة الأكاديمية: (أستاذ، أستاذ مشارك، أستاذ مساعد، محاضر، ، معيد).

ثانياً: المتغير التابع: تقدير درجة توفر معايير ضمان الجودة في البرامج الأكاديمية في كلية الشريعة والدراسات الإسلامية منادية من وجهة نظر أعضاء هيئة

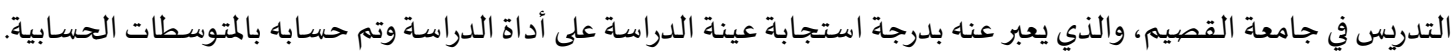

إجراءات تطبيق الدراسة: اتبع الباحث في تنفيذ إجراءات الدراسة الخطبقات الدراسهات الآتية: تحديد مجتمع وعينة الدراسـة.

تصميم أداة الدراسة (استبانة درجة تقدير توفر معايير ضمان الجودة في البرامج الأكاديمية في كلية الشريعة والدراسات الإسلامية في جامعة القصيم) وفق إجراءات البحث العلمي المعتمدة لمعايير الصدةق والثبات. تطبيق الاستبانة على عينة استطلاعية بلغ عددها (.r) عضيو هيئة تدريس. توزيع أداة الدراسة على عينة الدراسة والإجابة عن استفساراتهم وأسئلتهم. جمع البيانات وتفريغها ثم تحليلها إجراء التحليلات الإحصائية باستخدام البرنامج الإحصائي (SPSS)، للوصول إلى النتائج وتفسيرها والتوصيات.

المعالجات الإحصيائية:

تم استخدام المعالجات الإحصائية الآتية: المتوسطات الحسابية والانحرافات المعيارية للإجابة عن السؤال الأول والثاني.

• اختبار (Independent Sampled T - Test)، وتحليل التباين الأحادي ONE WAY) ANOVA)، واختبار (LSD) للمقارنات البعدية

$$
\text { نتائج الدراسـة ومناقشتها للإجابة عن السؤال الثاني. }
$$

أولا: النتائج المتعلقة بالسؤال الأول ومناقشته، وهو :"ما درجة توفر معايير ضيمان الجودة في البرامج الأكاديمية في كلية الشريعة والدراسات

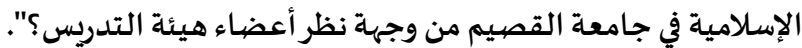

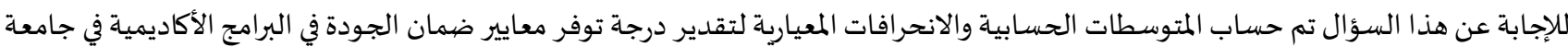
القصيم من وجهة نظر أعضاء هيئة التدريس. والجدول (7) يبين ذلك.

جدول (7): المتوسطات الحسابية والانحر افات المعيارية لتقديردرجة توفرمعايير ضمان الجودة في البرامج الأكاديمية في جامعة القصيم من وجهة نظر أعضاء

\begin{tabular}{|c|c|c|c|c|c|}
\hline درجة التوفر & الانحراف المعياري & المتوسط الحسابي & 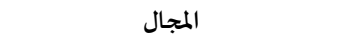 & 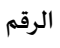 & 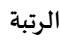 \\
\hline 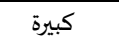 & ., & $r, v q$ & إدارة شؤون الطلبة والخدمات المساندة & ० & 1 \\
\hline كبيرة & ., OY & $r, v 7$ & الرسالة والغاية والأهداف & 1 & r \\
\hline كبيرة & . & $r, v r$ & عمليات التوظيف & $q$ & $r$ \\
\hline كبيرة &., $0 \varepsilon$ & $r, 77$ & التعلم والتعليم & $\varepsilon$ & $\varepsilon$ \\
\hline كبيرة & .,70 & $r, 7 \varepsilon$ & مصادر التعلم & 7 & 0 \\
\hline كبيرة & $1, \ldots$ & $r, \imath$. & إدارة ضمان جودة البرامج الأكاديمية & r & 7 \\
\hline كبيرة &., $0 \varepsilon$ & $r, O \mathrm{~V}$ & إدارة البرامج الأكاديمية & r & $\mathrm{v}$ \\
\hline متوسطة &., 01 & $r, r$ & المرافق والتجهيزات & $\mathrm{v}$ & $\wedge$ \\
\hline متوسطة & . & $r, .9$ & البحث العلمي & 1. & $q$ \\
\hline متوسطة &.,$\times 1$ & $r, .7$ & العلاقات مع المجتمع & 11 & 1. \\
\hline متوسطة & . AV & $r, \wedge 9$ & التخطيط والإدارة المالية & $\wedge$ & 11 \\
\hline كبيرة &.,$\Sigma 9$ & $r, \varepsilon\rceil$ & \multicolumn{3}{|c|}{ المتوسط الحسابي الكلي للأداة } \\
\hline
\end{tabular}
هيئة التدريس مرتبة تنازلياً حسب المتوسطات المعاير الحسابية. 
يبين الجدول (7) أن تقديرات أعضاء هيئة التدريس لدرجة توفر معايير ضمان الجودة في البرامج الأكاديمية في كلية الشريعة والدراسات الإسلامية في

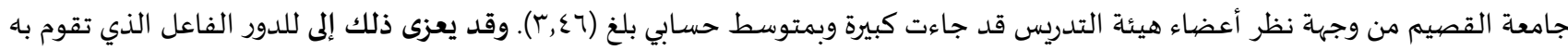

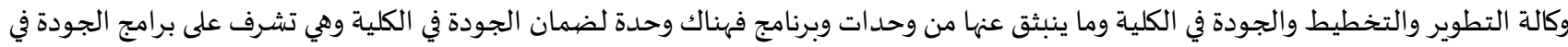

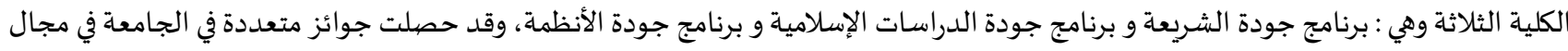
ضمان الجودة، هذا وقد تقدمت الكلية ببرنامج الشريعة للحصول على الاعتماد الأكاديمي للبرنامج من الهيئة الوطنية للتقويم والاعتماد الأكاديمي في بردي

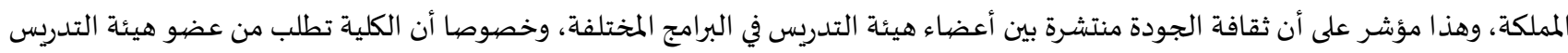

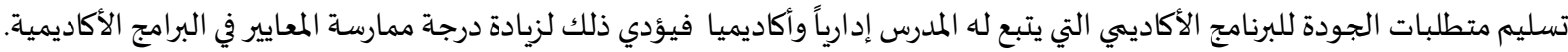

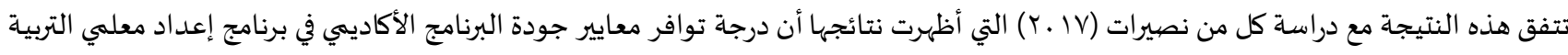

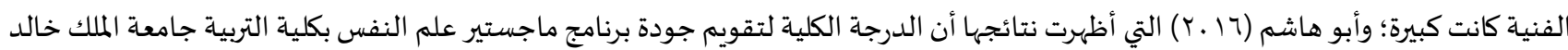

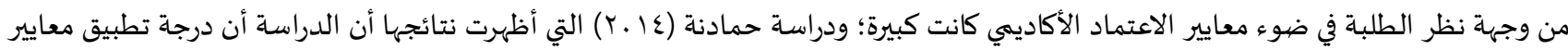

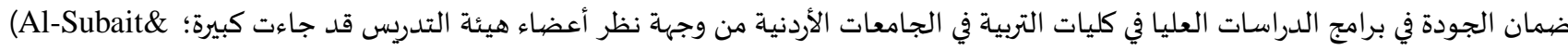

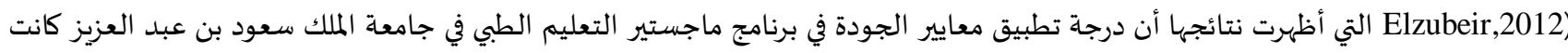

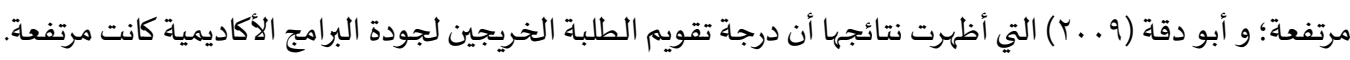

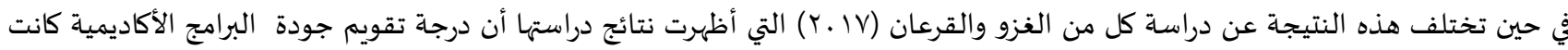

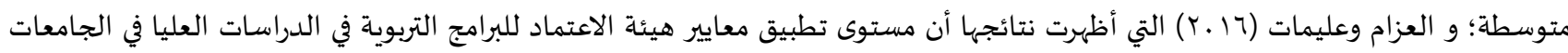

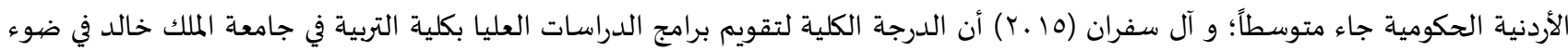

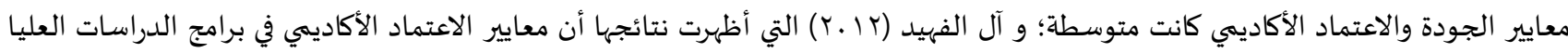

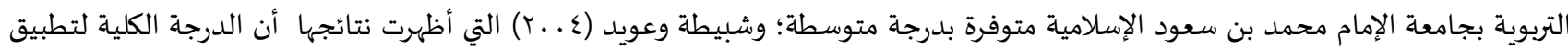

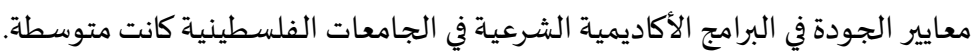

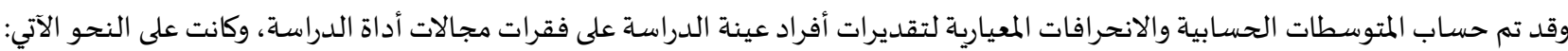
المجال الأول: الرسالة والغايات والأهداف وماف تم استخراج المتوسطات الحسابية والانحرافات المعيارية لفقرات مجال الرسالة والغايات والأهداف. كما هو مبين في الجدول (V).

جدول (V): المتوسطات الحسابية والانحر افات المعيارية لفقرات مجال الرسالة والغايات والأهداف مرتبة تنازلياً حسب المتوسطات الحسابية.

\begin{tabular}{|c|c|c|c|c|c|}
\hline 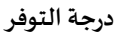 & 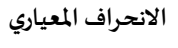 & المتوسط الحسابي & 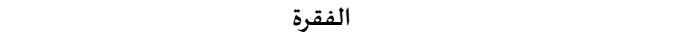 & 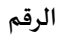 & 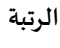 \\
\hline 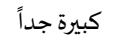 & $\cdot, \mathrm{VV}$ & $\varepsilon, 7 \vee$ & تتوافق الرسالة مع المعتقدات والقيم الإسلامية. & r & 1 \\
\hline 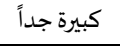 & $\cdot, \wedge \varepsilon$ & $\varepsilon, 7 \varepsilon$ & يتم اعتماد الرسالة رسميا من قبل الجهات المعنية داخل الجامعة. & $\wedge$ & r \\
\hline كبيرة & $1, \ldots$ & $r, q \varepsilon$ & ت ت تسق رسالة البرامج مع رسالة الجامعة. & 1 & r \\
\hline كبيرة & $1, r 1$ & $r, q$ & 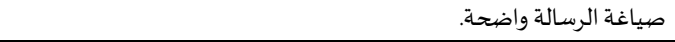 & 0 & $\varepsilon$ \\
\hline كبيرة & 1,11 & $r, 10$ & رسالة البرامج قابلة للتحقق. & $\varepsilon$ & 0 \\
\hline كبيرة & $1, r$. & $r, 7 \mathrm{~V}$ & توجه الرسالة غايات وأهداف البرامج. & $\mathrm{v}$ & 7 \\
\hline كبيرة & $1, r i$ & $r, 70$ & يتم مراجعة رسالة البرامج دوريا في ضوء الظروف المتغيرة. & 1. & $\mathrm{v}$ \\
\hline 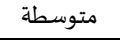 & I, Ir & $r, r r$ & تحدد الرسالة اتجاهات تطوير البرامج بما يتناسب وطبيعة واحتياجات الطلبة. & r & $\wedge$ \\
\hline متوسطة & l, Ir & $r, r$. & وجود وعي لدى أعضاء هيئة التدربس برسالة البرامج. & 9 & 9 \\
\hline 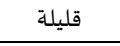 & $\cdot, \mathrm{Th}$ & $r, 01$ & مشاركة أعضاء هيئة التدريس في صياغة الرسالة. & 7 & 1. \\
\hline كبيرة & ., or & $r, v\urcorner$ & المتوسط الحسابي الكلي للمجال & & \\
\hline
\end{tabular}

يبين الجدول (V) المتوسطات الحسابية والانحرافات المعيارية لفقرات مجال (الرسالة والغايات والأهداف)، وتراوحت المتوسطات الحسابية تنازلياً

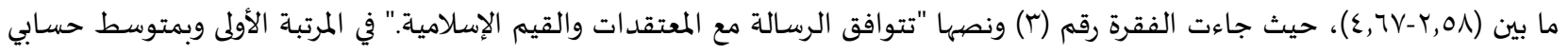

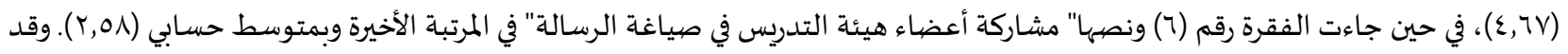

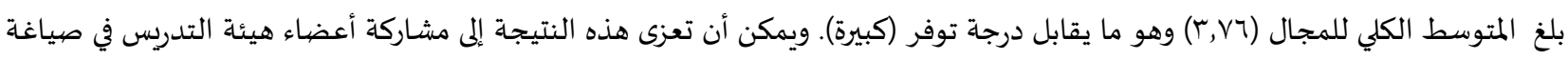

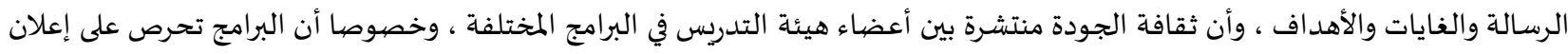

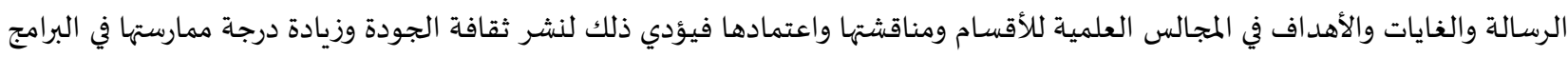




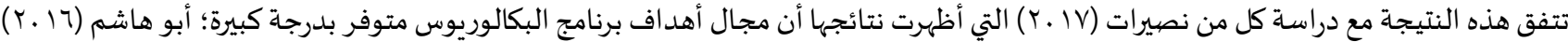

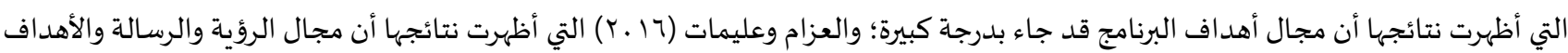

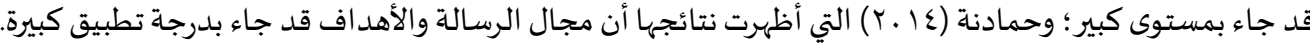

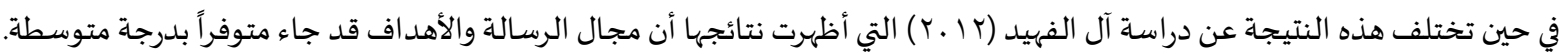
المجال الثاني: إدارة البرامج الأكاديمية تم استخراج المتوسطات الحسابية والانحرافات المعياربة لفقرات مجال إدارة البرامج الأكاديمية. كما هو مبين في الجدول (م). جدول (^) المتوسطات الحسابية والانحر افات المعيارية لفقرات مجال إدارة البرامج الأكاديمية مرتبة تنازلياً حسب المتوسطات الحسابية

\begin{tabular}{|c|c|c|c|c|c|}
\hline درجة التوفر & الانحراف المعياري & المتوسط الحسابي & 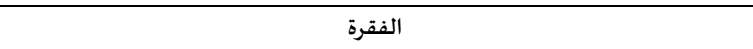 & 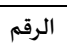 & 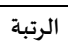 \\
\hline كبيرة جداً &., 01 & $\varepsilon, \wedge \varepsilon$ & وجود وصف وظيفي واضح لرئيس القسم. & 1 & 1 \\
\hline كبيرة جداً &., $\mathrm{OV}$ & $\varepsilon, \Lambda$ K & يلتزم أعضاء هيئة التدريس بقواعد الممارسات الأخلاقية والسلوك في كافة واجباتهم ومهامههم & 1. & r \\
\hline كبيرة & $\cdot, 91$ & $\varepsilon, 17$ & مشاركة أعضاء هيئة التدريس في التخطيط للبرامج. & 1 & $r$ \\
\hline كبيرة &., 99 & $\varepsilon, 10$ & التعلم، والتقويم). & $\mathrm{v}$ & $\varepsilon$ \\
\hline كبيرة & $1,1 \mathrm{r}$ & $r, \varepsilon \varepsilon$ & بعيدة المدىى. & $\wedge$ & 0 \\
\hline متوسطة & 1,10 & r, ז & تشجع إدارة البرامج مبادرات أعضياء هيئة التدريس وتكافيها. & r & 7 \\
\hline 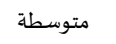 & $1,1 \mathrm{~V}$ & r, r & تقدم إدارة البرامج تقارير دورية عن أداء أعضياء هيئة التدريس في القسم. & $\varepsilon$ & 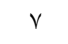 \\
\hline 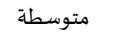 & 1,19 & $r, . r$ & وجود خطط استراتيجية للبرامج تراعي العوامل البيئة الداخلية والخارجية. & $\circ$ & $\wedge$ \\
\hline متوسطة &., 91 & T,10 & تتحمل إدارة البرامج المسؤولية عن جودة أنشطة البرامج وفاعليتها. & $r$ & 9 \\
\hline متوسطة &., $9 \vee$ & r, Vq & تراجع خطط البرامج دوريا في ضوء المتغيرات. & 9 & 1. \\
\hline قليلة & $\cdot, \uparrow$ & $r, 0 \Lambda$ & الإعلان عن المصادر المالية المخصصية للبرامج في القسم. & 11 & 11 \\
\hline 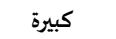 &., $0 \varepsilon$ & r,ov & المتوسط الحسـابي الكلي للمجال & & \\
\hline
\end{tabular}

يبين الجدول (^) المتوسطات الحسابية والانحرافات المعيارية لفقرات مجال (إدارة البرامج الأكاديمية)، وتراوحت المتوسطات الحسابية تنازلياً ما

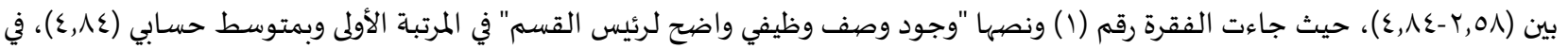

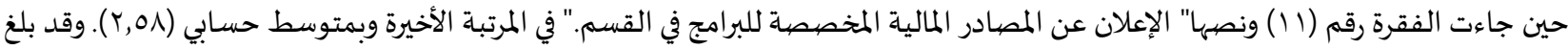

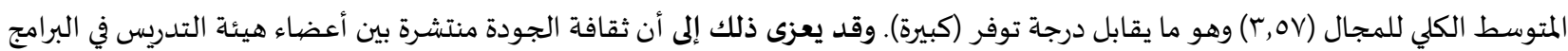

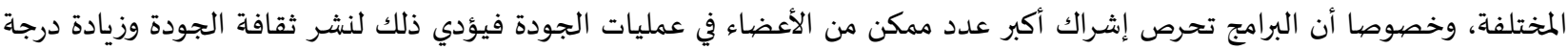
ممارستها في البرامج الأكاديمية.

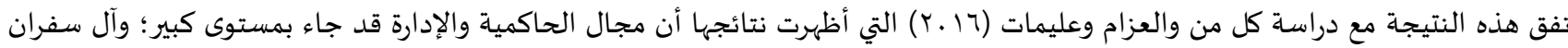

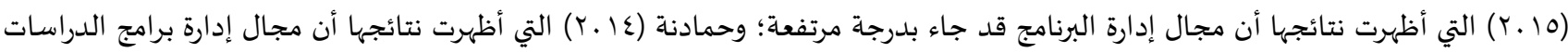
العليا قد جاء بدرجة تطبيق كبيرة.

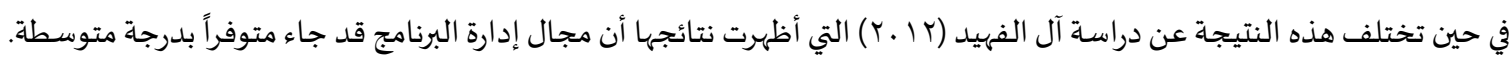

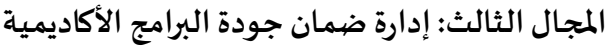
تم استخراج المتوسطات الحسابية والانحرافات المعيارية لفقرات مجال إدارة ضمانمان جوان المودة البرامج الأكاديمية. كما هو مبين في الجدول (9). جدول (9): المتوسطات الحسابية والانحر افات المعيارية لفقرات مجال إدارة ضيمان جودة البرامج الأكاديمية مرتبة تنازلياً حسب المتوسطات الحسابية.

\begin{tabular}{|c|c|c|c|c|c|}
\hline التوفر & المعياري & المتوسط الحسابي & الفقرة & 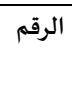 & الرتبة \\
\hline كبيرة & $1,1 \%$ & $\varepsilon, 10$ & تبنى عمليات التقويم الذاتي على مؤشرات محددة مسبقا & 0 & 1 \\
\hline كبيرة & $1,1 \mathrm{~V}$ & $\varepsilon, \mid T$ & الاستعانة بخبراء مستقلين للتأكد من نتائج عمليات التقويم الذاتي & 7 & r \\
\hline متوسطة & 1, ro & $r, r \Lambda$ & تتضمن عمليات التقويم استيفاء معايير ضمان الجودة والاعتماد الأكاديمي في البرامج. & $\varepsilon$ & $r$ \\
\hline متوسطة & $1, T V$ & $r, r u$ & شمولية عمليات التقويم الذاتي للمدخلات والعمليات والمخرجات وتركيزها بشكل أكبر على المخرجات & $r$ & $\varepsilon$ \\
\hline 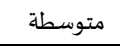 & $1, r 7$ & $r, r+r$ & مشاركة أعضاء هيئة التدريس في عمليات التقويم الذاتي للبرامج & 1 & 0 \\
\hline 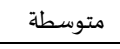 & 1, rی & $r, Y]$ & تشجع إدارة البرامج الإبداع والابتكار في إطار السياسات والإرشادات والمساءلة & r & 7 \\
\hline كبيرة & $1, \ldots$ & $r, \uparrow$. & المتوسط الحسابي الكلي للمجال & & \\
\hline
\end{tabular}


يبين الجدول (9) المتوسطات الحسابية والانحرافات المعيارية لفقرات مجال (إدارة ضمان جودة البرامج الأكاديمية)، وتراوحت المتوسطات

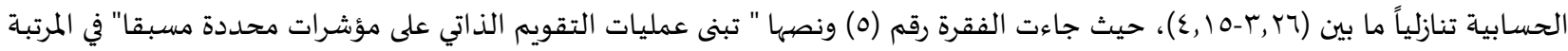
الأولى وبمتوسط حسابي (10,10)، في حين جاءت الفقرة رقم (Y) ونصها " تشجع إدارة البرامج الإبداع والابتكار في إطار السياسات والإرشادات

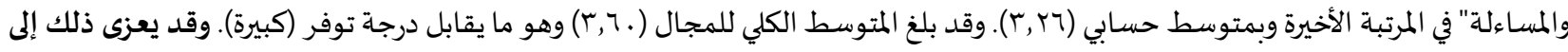
أن ثقافة الجودة منتشرة بين أعضياء هيئة التدريس في البرامج المختلفة، وخصوصيا أن البرامج تحرص إشراك أكبر عدد ممكن من الأعضاء في

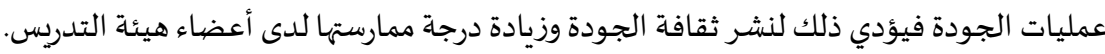

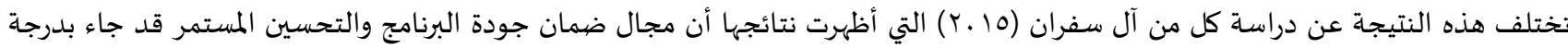

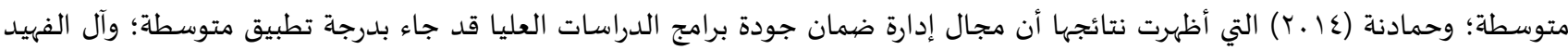

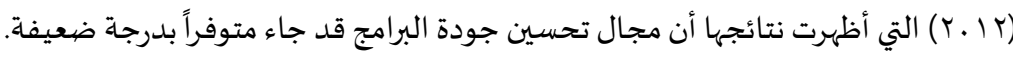
المجال الر ابع: التعلم والتعليم

تم استخراج المتوسطات الحسابية والانحرافات المعيارية لفقرات مجال التعلم والتعليم. كما هو مبين في الجدول (. ().

جدول ( ـ ا): المتوسطات الحسابية والانحر افات المعيارية لفقرات مجال التعلم والتعليم مرتبة تنازلياً حسب المتوسطات الحسابية

\begin{tabular}{|c|c|c|c|c|c|}
\hline 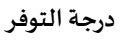 & 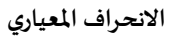 & المتوسط الحسابي & 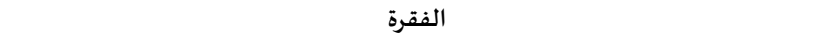 & 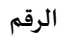 & الرتبة \\
\hline كبيزة & $1, .9$ & $\varepsilon, 1 \wedge$ & وجود وصف واضح لمخرجات التعلم المطلوبة من البرامج. & 1 & 1 \\
\hline كبيرة & $1, r \pi$ & $\varepsilon, 17$ & مناسبة خبرات ومؤهلات أعضاء هيئة التدريس للمقررات التي يدرسونها. & 10 & r \\
\hline كبيرة &., 97 & $\varepsilon, 10$ & وجود برامج للتنمية المهنية لجميع أعضياء هيئة التدريس. & Ir & $r$ \\
\hline كبيرة &., 91 & $\varepsilon, 1 \Gamma$ & وجود برامج للهيئة والتدربب في مهارات التدريس لأعضاء هيئة التدربس. & IT & $\varepsilon$ \\
\hline كبيرة & $\cdot, 99$ & $\varepsilon, 1 r$ & وجود آليات للتأكد من مدى تحقيق الطلبة لنواتج التعلم المطلوبة. & $r$ & 0 \\
\hline كبيزة & $1, \ldots$ & $\varepsilon, 1$. & تتضمن الخطط الدراسية معلومات تفصيلية عن (المعارف والمهارات المطلوبة، واستراتيجيات & $\varepsilon$ & 7 \\
\hline كبيرة & $1, .0$ & $\varepsilon, \cdot \Lambda$ & يتفق محتوى المقررات الدراسية واستراتيجيات التعلم المستخدمة. & 0 & $\checkmark$ \\
\hline كبيزة & $1, .9$ & $\varepsilon, .7$ & يتم تقويم أعمال الطلبة بصهورة عادلة وموضيوعية. & 9 & $\wedge$ \\
\hline كبيرة & $1, r$ & $\varepsilon, \cdot \varepsilon$ & تتصف الكتب المقررة في الخطة بالحداثة. & $1 \varepsilon$ & 9 \\
\hline متوسطة & 1,17 & r,ra & يعطى الطلبة تغذية راجعة عن أدائهم ونتائج تقويمهم. & 11 & 1. \\
\hline متوسطة & 1,19 & r,ז人 & توضح آليات التقويم عند بداية تقربر المقررات الدراسية. & $\Lambda$ & 11 \\
\hline متوسطة & $1, \pi$ & $r, r u$ & يتم تقويم المقررات الدراسية واستراتيجيات التعلم بصورة دورية. & 7 & ir \\
\hline متوسطة & $1, r \varepsilon$ & r, ro & تتوافق مخرجات التعلم مع متطلبات المؤهلات الوطنية. & $r$ & ir \\
\hline متوسطة & $1, r V$ & r ז, & يهيئ أعضاء هيئة التدريس الطلبة قبل الذهاب إلى الميدان من خلال اللقاءات التعريفية والدروس & IV & $1 \varepsilon$ \\
\hline متوسطة & $1, r_{1}$ & r,Tr & يحدد أعضاء هيئة التدريس أوقات كافية ومحددة لتقديم المشورة والإرشاد للطلبة. & 1. & 10 \\
\hline متوسطة & $1, r V$ & r, r. & تتفق آليات تقويم الطلبة مع أنماط التعلم المطلوبة. & v & 17 \\
\hline قليلة جداً & 1,00 & 1,19 & يقوم أعضاء هيئة التدريس بزيارات ميدانية للطلبة. & 17 & iv \\
\hline 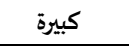 &., $0 \varepsilon$ & $r, 77$ & المتوسط الحسابي الكلي للمجال & & \\
\hline
\end{tabular}

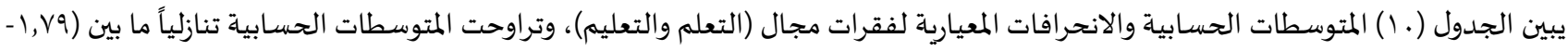

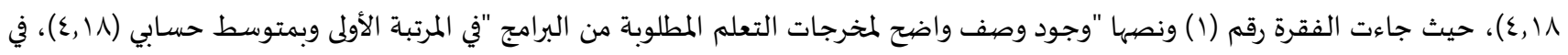

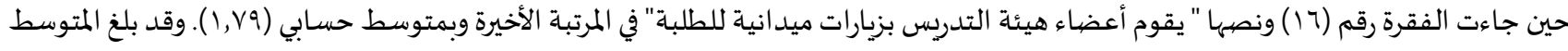

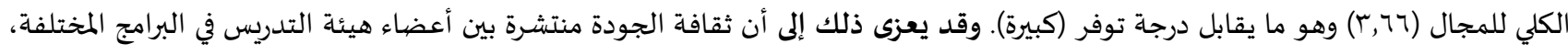
وخصوصا أن البرامج تحرص إشراك أكبر عدد ممكن من الأعضاء في عمليات الجودة فيؤدي ذلك لنشر ثقافة الجودة وزيادة درجة ممارستها في البرامج الأكاديمياة.

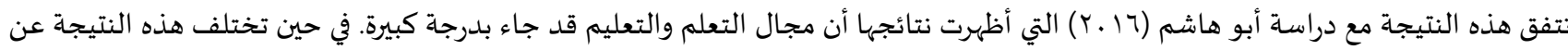

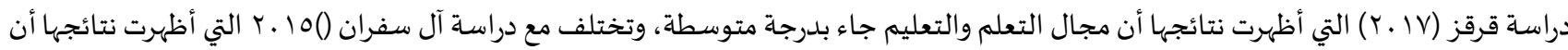

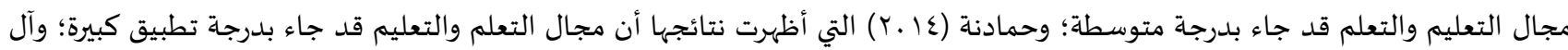

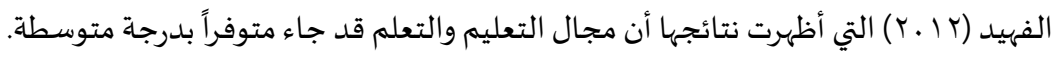


المجال الخامس: إدارة شؤون الطلبة والخدمات المسـاندة

تم استخراج المتوسطات الحسابية والانحرافات المعيارية لفقرات مجال إدارة شؤون الطلبة والخدمات إدوات المساندة. كما هو مبين في الجدول (1).

جدول (1 (1): المتوسطات الحسابية والانحر افات المعيارية لفقرات مجال إدارة شؤون الطلبة والخدمات المساندة مرتبة تنازلياً حسب المتوسطات الحسابية

\begin{tabular}{|c|c|c|c|c|c|}
\hline 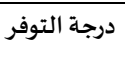 & الانحراف المعياري & المتوسط الحسابي & 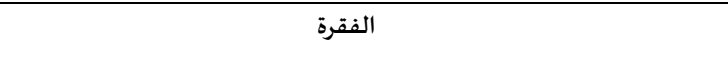 & 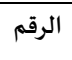 & 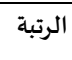 \\
\hline كبيرة جداً & . हT & $\varepsilon, \Lambda$ & تطبق متطلبات قبول الطلبة في البرامج بشكل عادل وموضوعي. & 1 & 1 \\
\hline كبيرة جداً &., 01 & $\varepsilon, \wedge \varepsilon$ & يتم التحقق رسميا من استيفاء الطلبة لمتطلبات التخرج. & $\checkmark$ & r \\
\hline كبيرة &., 99 & $r, 91$ & يتم الإعلان بالوسائل المختلفة عن نتائج قبول الطلبة. & r & $r$ \\
\hline كبيرة & $1, .0$ & $r, 91$ & وجود برامج إرشادية لتهيئة الطلبة الجدد. & $\varepsilon$ & $\varepsilon$ \\
\hline كبيرة & $1,1$. & $r, 7 \varepsilon$ & وجود سجلات مبرمجة لمتابعة تحصيل الطلبة. & 0 & $\circ$ \\
\hline كبيرة & $1,1 \varepsilon$ & $r, 09$ & وجود آليات لتلقي تظلمات الطلبة. & $\Lambda$ & 7 \\
\hline كبيرة & 1,14 & $r, 07$ & وجود آليات للتعامل مع السلوكيات الأكاديمية غير المقبولة. & 9 & v \\
\hline كبيرة & 1,10 & r,or & وجود آليات تحكم سرية معلومات سجلات الطلبة. & 7 & $\Lambda$ \\
\hline متوسطة & $1, Y$ & $r, r$ r & وجود نظام دعم لحل مشكلات الطلبة (ماليا، ونفسيا، وصحيا، وعائليا، وشخصيا). & 11 & 9 \\
\hline متوسطة & $1, r \mathrm{r}$ & $r, r 7$ & وجود مرشدون ملمون بتفاصيل متطلبات المقررات لإرشاد الطلبة. & $r$ & 1. \\
\hline 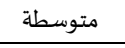 & $1, r 1$ & r, r, & وجود برامج للإرشاد الأكاديمي والمني للطلبة. & 1. & 11 \\
\hline 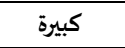 & ., 7 . & r,vq & المتوسط الحسابي الكلي للمجال & & \\
\hline
\end{tabular}

يبين الجدول (1) المتوسطات الحسابية والانحرافات المعيارية لفقرات مجال (إدارة شؤون الطلبة والخدمات المساندة)، وتراوحت المتوسطات

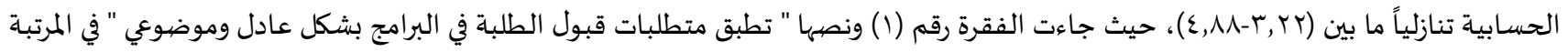

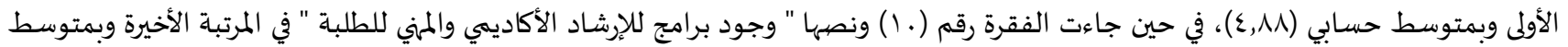

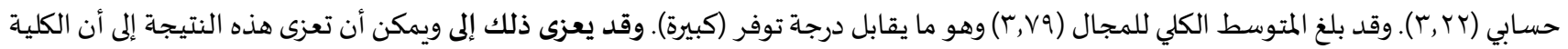

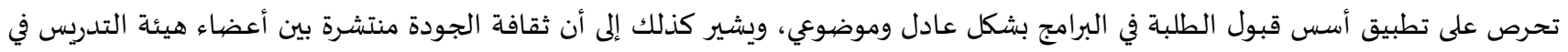

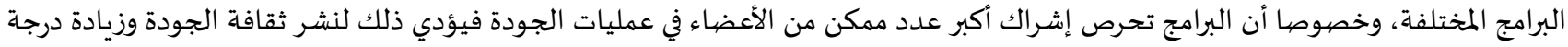
ممارستها في البرامج الأكاديمية.

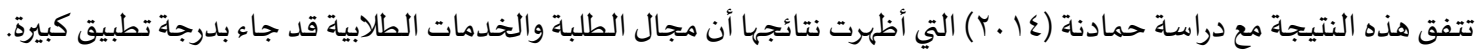

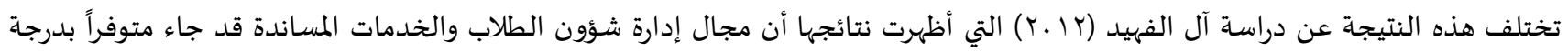
متوسطة. المجال السادس: مصيسادر التعلم

تم استخراج المتوسطات الحسابية والانحرافات المعيارية لفقرات مجال مصادر التعلم. كما هو مبين في الجدول (r ا )

جدول(Y ( ): المتوسطات الحسابية والانحر افات المعيارية لفقرات مجال مصادر التعلم مرتبة تنازلياً حسب المتوسطات الحسابية

\begin{tabular}{|c|c|c|c|c|c|}
\hline 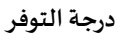 & الانحراف المعياري & المتوسط الحسابي & 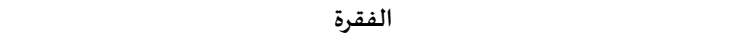 & 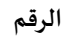 & الرتبة \\
\hline 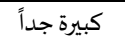 & $\cdot$, TV & $\varepsilon, \wedge 0$ & سهولة الوصول إلى قواعد البيانات الإلكترونية والمجلات. & r & 1 \\
\hline 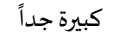 & $\cdot, \mathrm{Vr}$ & $\varepsilon, \lambda r$ & وجود أنظمة إلكترونية تساعد الوصول إلى مصادر المعلومات داخل الجامعة وخارجها. & 0 & r \\
\hline كبيرة & $1,1 \mathrm{~T}$ & $r, \leq 0$ & إمكانية استفادة أعضاء هيئة التدريس من خدمات المكتبة لساعات طويلة. & 1 & $r$ \\
\hline كبيرة & $1,1 \pi$ & $r, \varepsilon \varepsilon$ & توفر عدد كاف من الكتب والمجلات لتلبية احتياجات البرامج. & 1 & $\varepsilon$ \\
\hline كبيرة & 1,17 & $r, \varepsilon r$ & كفاية المرافق والتجهيزات في المكتبة بما يتلاءم مع احتياجات البرامج. & $\mathrm{v}$ & 0 \\
\hline متوسطة & .,9r & r,10 & توفر المكتبة برامج إرشادية لأعضاء هيئة التدريس لاستخدام مرافقها. & v & 7 \\
\hline متوسطة & $\cdot, 71$ & $r, \pi$ & توفر المكتبة خدمة توفير المراجع من جامعات أخرى. & $\varepsilon$ & v \\
\hline كبيرة & .07 & $r, 7 \varepsilon$ & المتوسط الحسابي الكلي للمجال & & \\
\hline
\end{tabular}

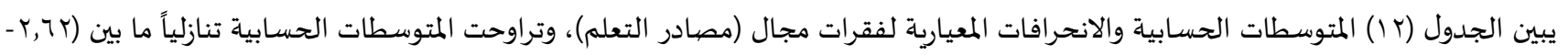

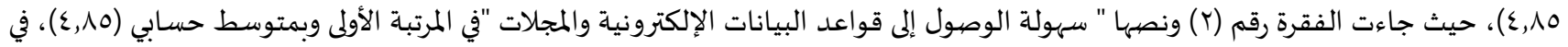

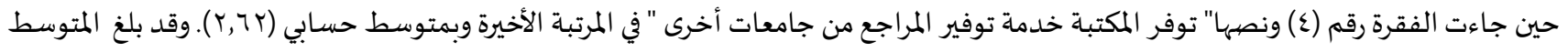

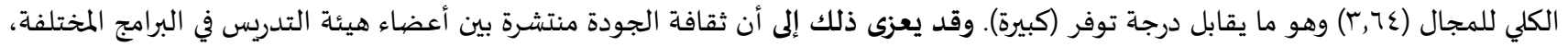


وخصوصا أن البرامج تحرص إشراك أكبر عدد ممكن من الأعضاء في عمليات الجودة فيؤدي ذلك لنشر ثقافة الجودة وزيادة درجة ممارستها في البرامج الأكاديمياة.

تختلف هذه النتيجة عن دراسة كل من العزام وعليمات (10 • ) التي أظهرت نتائجها أن مجال المصادر قد جاء بمستوى متوسط؛ وآل سفران (10 . ب)

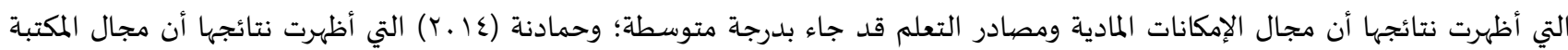
ومصادر التعلم قد جاء بدرجة تطبيق كبيرة؛ وآل الفهيد (Y ا ـ Y) التي أظهرت نتائجها أن مجال مصادر التعلم قد جاء متوفراً بدرجة متوسطة. المجال السـابع: المر افق والتجهيزات

تم استخراج المتوسطات الحسابية والانحرافات المعيارية لفقرات مجال المرافق والتجهيزات. كما هو مبين في الجدول (rار).

جدول (rا ): المتوسطات الحسابية والانحر افات المعيارية لفقرات مجال المر افق والتجهيزات مرتبة تنازلياً حسب المتوسطات الحسابية

\begin{tabular}{|c|c|c|c|c|c|}
\hline درجة التوفر & الانحراف المعياري & المتوسط الحسابي & الفقرة & 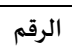 & 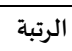 \\
\hline كبيرة جداً & $1, .0$ & $\varepsilon, r \varepsilon$ & توفر متطلبات الصحة والسلامة في المرافق والتجهيزات. & $r$ & 1 \\
\hline كبيرة & 1,10 & $r, 90$ & توفر مرافق وتجهيزات بما يلبي احتياجات البرامج. & 1 & r \\
\hline كبيرة &., 90 & $r, \Lambda$ & توفر وسائل وخدمات لذوي الاحتياجات الخاصة. & $\varepsilon$ & $r$ \\
\hline متوسطة &., 71 & T,Tr & والبحثية المرافق والتجهيزات لممارسة أعضاء هيئة التدريس والطلبة لأنشطهم الأكاديمية & $r$ & $\varepsilon$ \\
\hline متوسطة & 1,01 & I,Nr & مناسب أجهزة الحواسيب والبرمجيات لاحتياجات البرامج. & 。 & 。 \\
\hline متوسطة &., 01 & $r, r$, & المتوسط الحسابي الكلي للمجال & & \\
\hline
\end{tabular}

يبين الجدول (rا (المتوسطات الحسابية والانحرافات المعيارية لفقرات مجال (المرافق والتجهيزات)، وتراوحت المتوسطات الحسابية تنازلياً ما بين

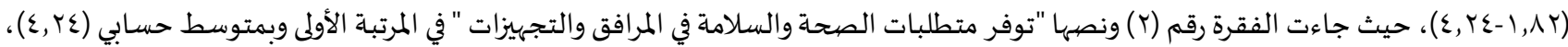

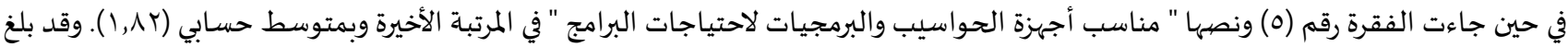

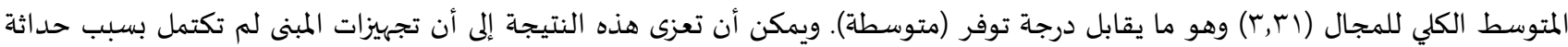
الانتقال إلى المبنى الجديد للكلية وما زالت عطاءات التجهيز قائمة وتكتمل أولاً بأول

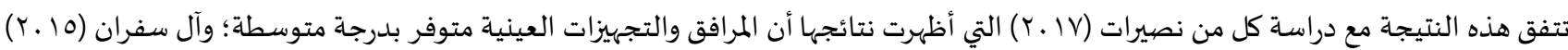

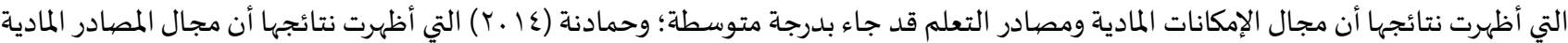

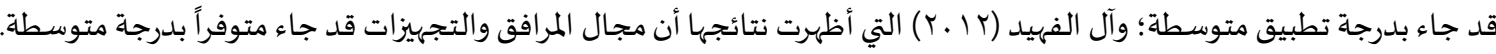

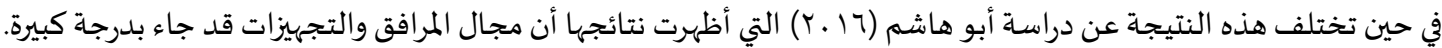
المجال الثامن: التخطيط والإدارة المالية

تم استخراج المتوسطات الحسابية والانحرافات المعيارية لفقرات مجال التخطيط والإدارة المالية. كما هو مبين في الجدول (1).

جدول (ع ()): المتوسطات الحسابية والانحر افات المعيارية لفقرات مجال التخطيط والإدارة المالية مرتبة تنازلياً حسب المتوسطات الحسابية

\begin{tabular}{|c|c|c|c|c|c|}
\hline 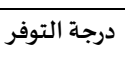 & الانحراف المعياري & المتوسط الحسابي & 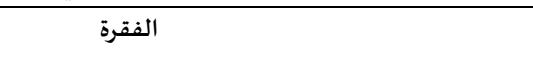 & 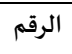 & 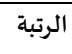 \\
\hline متوسطة & $1, r \varepsilon$ & r, r, & وجود نظام محاسبي تخضع له ميزانية البرامج. & $\varepsilon$ & 1 \\
\hline متوسطة & $1, r \varepsilon$ & $r, r 4$ & يتم إعداد تقارير دورية عن ميزانية البرامج طوال السنة. & o & r \\
\hline متوسطة & $1, r \varepsilon$ & r, ro & توفر موارد مالية كافية لتقديم برامج عالية الجودة. & 1 & $r$ \\
\hline قليلة &., $\mathrm{VT}$ & r,OA & وجود وصف واضح للصلاحيات المالية للبرامج. & r & $\varepsilon$ \\
\hline قليلة جداً & 1,00 & 1,199 & مشاركة أعضاء هيئة التدربس في عملية التخطيط للميزانية. & 0 & 0 \\
\hline متوسطة &.,$A V$ & r,Aq & المتوسط الحسابي الكلي للمجال & & \\
\hline
\end{tabular}

يبين الجدول (ع ا) المتوسطات الحسابية والانحرافات المعيارية لفقرات مجال (التخطيط والإدارة المالية)، وتراوحت المتوسطات الحسابية تنازلياً ما بين

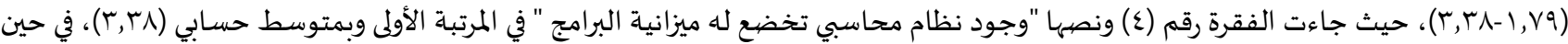
جاءت الفقرة رقم (0) ونصها " مشاركة أعضاء هيئة التدريس في عملية التخطيط للميزانية " في المرتبة الأخيرة وبمتوسط حسابي (1,V9). وقد بلغ

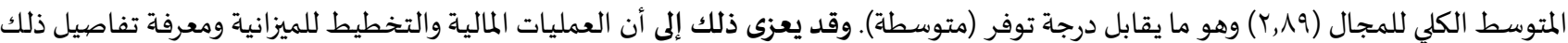
ليست من اختصاص أعضاء هيئة التدريس ، وكما أن عضو هيئة التدريس لا يعتني بمعرفة الأمور المالية . 
المجال التاسع: عمليات التوظيف

تم استخراج المتوسطات الحسابية والانحرافات المعيارية لفقرات مجال عمليات التوظيف. كما هو مبين في الجدول (10).

جدول (10): المتوسطات الحسابية والانحر افات المعيارية لفقرات مجال عمليات التوظيف مرتبة تنازلياً حسب المتوسطات الحسابية

\begin{tabular}{|c|c|c|c|c|c|}
\hline 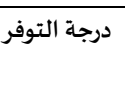 & المعياري & المتوسط المسابي & 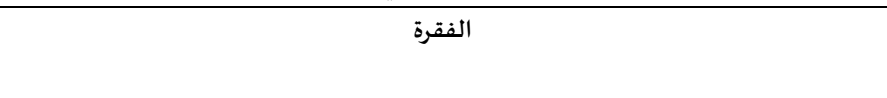 & 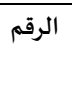 & 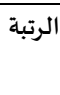 \\
\hline كبيرة & 1,14 & $r, 91$ & تتضمن عملية توظيف أعضاء هيئة التدربس خبراتهم ومهاراتهم وسماتهم الشخصية التي تفي بمتطلبات & 1 & 1 \\
\hline كبيرة & 1,17 & $r, 9 \leq$ & يتم التحقق من صحة المؤهلات والخبرات الخاصة بالمرشحين قبل تعيينهم. & $r$ & r \\
\hline كبيرة & $1, r \varepsilon$ & $r, \wedge 9$ & يعطى جميع أعضاء هيئة التدريس فرصا عادلة ومناسبة للتطوير الشخصي والممني. & $\circ$ & $r$ \\
\hline كبيرة & $1,1 T$ & $r, 7$. & يتم تقويم أداء أعضاء هيئة التدريس بسرية تامة مع توثيقها وحفظها. & $\varepsilon$ & $\varepsilon$ \\
\hline متوسطة & 1,0 . & $r, r$ r & يتم تزويد المرشحين للتوظيف ببيانات كاملة عن مواصفات الوظيفة وشروط التعيين فهها. & r & $\circ$ \\
\hline كبيرة & r, & $r, V r$ & المتوسط الحسابي الكلي للمجال & & \\
\hline
\end{tabular}

يبين الجدول (10) المتوسطات الحسابية والانحرافات المعيارية لفقرات مجال (عمليات التوظيف)، وتراوحت المتوسطات الحسابية تنازلياً ما بين

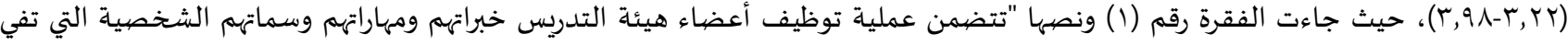

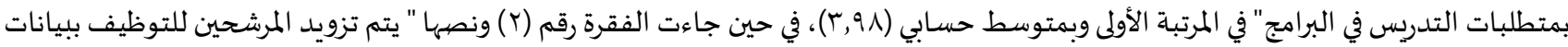
كاملة عن مواصفات الوظيفة وشروط التعيين فها " في المرتبة الأخيرة وبمتوسط حسابي (r,Y,Y). وقد بلغ المتوسط الكلي للمجال (r,Y, وهو ما يقابل

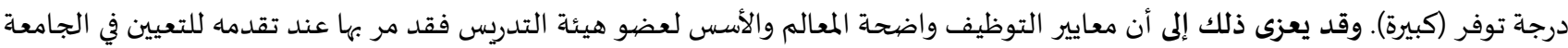
وهي تركز على الكفاءة العلمية والمهنية وتحرص على تطوير مهاراتهم الأدائية سواء دورات تهيئة المدرسين الجدد ، وكما يركز في مجالس الأقسام على المهائ

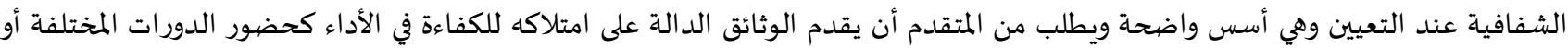

تقديمها مما انعكس على الحكم بممارسة المعيار التاسع بدرجة كبيرة.

المجال العاشر: البحث العلمي

تم استخراج المتوسطات الحسابية والانحرافات المعيارية لفقرات مجال البحث العلمي. كما هو مبين في الجدول (1 ).

جدول (17) : المتوسطات الحسابية والانحر افات المعيارية لفقرات مجال البحث العلمي مرتبة تنازلياً حسب المتوسطات الحسابية

\begin{tabular}{|c|c|c|c|c|c|}
\hline التوفر & المعياري & الحستوسطي & 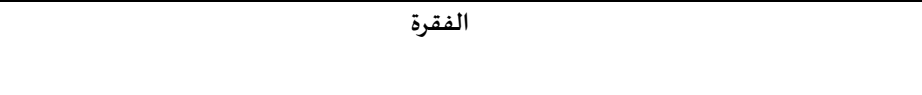 & الرقم & 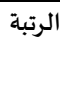 \\
\hline متوسطة & $1, r \varepsilon$ & $r, r q$ & تتسم بحوث أعضاء هيئة التدريس بالأصالة والابتكار. & r & 1 \\
\hline متوسطة & $1, r \varepsilon$ & $r, r$ r & توفر المرافق والتجهيزات اللازمة لإجراء البحوث. & 7 & r \\
\hline متوسطة & $\mid, Y)$ & $r, r r$ & توفر الدعم المالي اللازم لإجراء البحوث. & 0 & $r$ \\
\hline 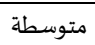 & $1, r)$ & r,tr & وجود آليات واضحة تحدد التوقعات المتعلقة بمشاركة أعضاء هيئة التدريس في الأنشطة البحثية والعلمية. & 1 & $\varepsilon$ \\
\hline قليلة & 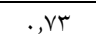 & $\mathrm{r}, \mathrm{OV}$ & توفر الدعم الكافي لمساعدة أعضاء هيئة التدريس الجدد في تطوير برامجهم البحثية. & $r$ & 0 \\
\hline قليلة & $\cdot, \mathrm{V} r$ & r,07 & يتاح لطلبة الدراسات العليا فرصة المشاركة في مشروعات الأبحاث المشتركة. & $\varepsilon$ & 7 \\
\hline متوسطة & ., ו & $r, .9$ & المتوسط الحسابي الكلي للمجال & & \\
\hline
\end{tabular}

يبين الجدول (17) المتوسطات الحسابية والانحرافات المعيارية لفقرات مجال (البحث العلمي)، وتراوحت المتوسطات الحسابية تنازلياً ما بين (r,07 -

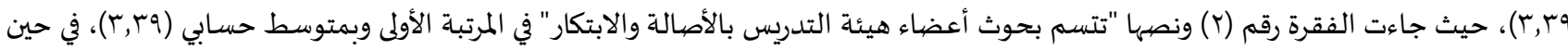

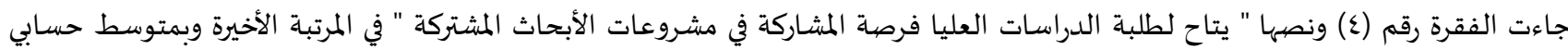
(Y,07). وقد بلغ المتوسط الكلي للمجال (r,Vr) وهو ما يقابل درجة توفر (متوسطة). وقد يعزى ذلك ألك إلى ويمكن أن تعزى هذه النتيجة إلى أن هناك

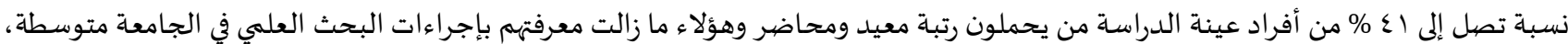

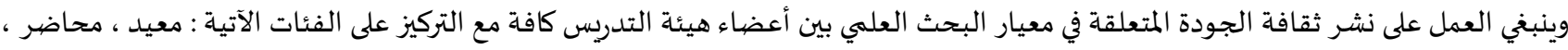
أستاذ مساعد

تتفق هذه النتيجة مع دراسة كل من العزام وعليمات (10 ـ (Y) التي أظهرت نتائجها أن مجال البحث العلمي وتبادل التعليم قد جاء بمستوى

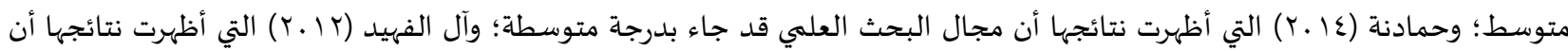


مجال البحث العلمي قد جاء متوفراً بدرجة متوسطة؛ وشبيطة وعويد (ع . ب) التي أظهرت نتائجها أن مجال جودة البحث العلمي قد جاء بدرجة تطبيق متوسطة.

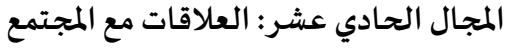
تم استخراج المتوسطات الحسابية والانحرافات المعيارية لفقرات مجال العلاقات مع المجتمع. كما هو مبين في الجدول (IV).

جدول (IV): المتوسطات الحسابية والانحر افات المعيارية لفقرات مجال العلاقات مع المجتمع مرتبة تنازلياً حسب المتوسطات الحسابية

\begin{tabular}{|c|c|c|c|c|c|}
\hline 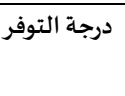 & المعياري & المستوسط الحسب & 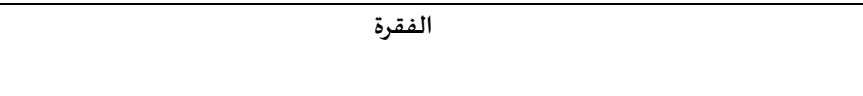 & 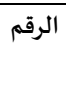 & الرتبة \\
\hline كبيرة جداً &., 94 & $\varepsilon, r$ & ترتبط ترقية أعضاء هيئة التدريس وتقييم أدائهم بالخدمات التي يقدمونها للمجتمع المحلي. & $r$ & 1 \\
\hline متوسطة & $1, r \mathrm{r}$ & $r, r$. & يتم إعداد تقارير سنوية حول الخدمات التي تقدم للمجتمع المحلي. & r & r \\
\hline متوسطة & $1, r$ T & $r, r \wedge$ & مشاركة أعضاء هيئة التدريس في الندوات والمؤتمرات ذات مساس بالمجتمع المحلي. & 0 & r \\
\hline متوسطة & 1,19 & $r, T V$ & ينسق إدارة البرامج مع الوحدات المعنية في الجامعة بشأن مبادرات خدمة المجتمع، منعا من تكرارها. & $\varepsilon$ & $\varepsilon$ \\
\hline متوسطة & $1, r$ r & $r, r 7$ & وجود وصف واضح للخدمات التي تقدمها البرامج للمجتمع المحلي. & 1 & 0 \\
\hline متوسطة & 1,0 . & $r, r t$ & تقيم إدارة البرامج علاقات وطيدة مع مؤسسات المجتمع المحلي. & 7 & 7 \\
\hline قليلة &., $\mathrm{V} 7$ & $r, \sum \Lambda$ & وجود قاعدة بيانات تشمل النشاطات التي يقوم بها أعضاء هيئة التدريس في خدمة المجتمع المحلي. & 9 & $\mathrm{~V}$ \\
\hline قليلة & $1, \wedge \varepsilon$ & $r, r$. & ترتبط إدارة البرامج بصلات مستمرة مع المدارس الموجودة في المجتمع المحلي. & $\mathrm{v}$ & $\wedge$ \\
\hline 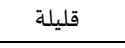 & $1, v_{0}$ & r, M & تحافظ إدارة البرامج على تواصل فعال مع خربجي البرامج. & $\wedge$ & 9 \\
\hline متوسطة &., $\mathrm{VI}$ & $r, .7$ & المتوسط الحسابي الكلي للمجال & & \\
\hline
\end{tabular}

يبين الجدول (VI) المتوسطات الحسابية والانحرافات المعيارية لفقرات مجال (البحث العلمي)، وتراوحت المتوسطات الحسابية تنازلياً ما بين

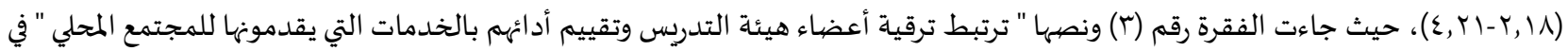
المرتبة الأولى وبمتوسط حسـابي (آ, ع)، في حين جاءت الفقرة رقم (^) ونصها " تحافظ إدارة البرامج على تواصل فعال مع خريجي البرامج " في المرتبة

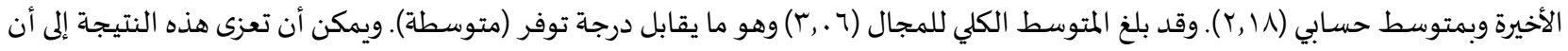

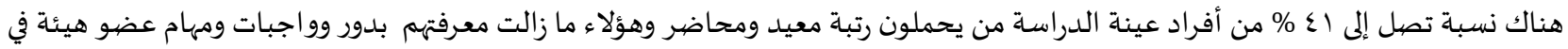

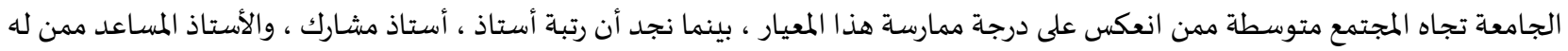

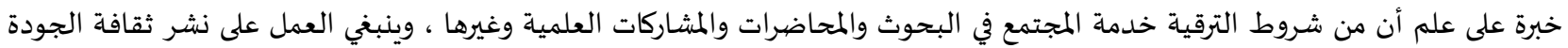

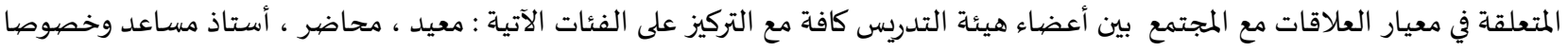
حديث التعيين أو المتعاقد معهم من خارج المملكة.

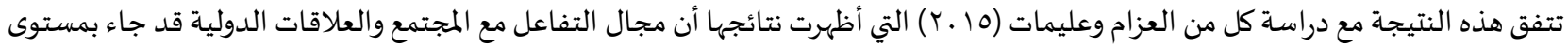

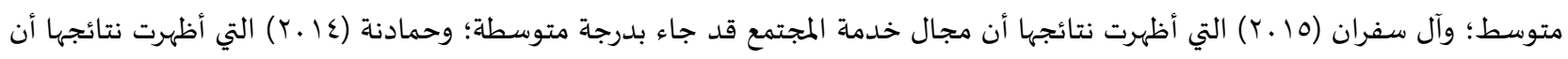

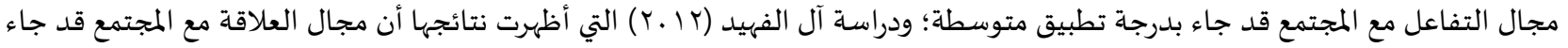
متوفراً بدرجة متوسطة. ثانياً: النتائج المتعلقة بالسؤال الثاني ومناقشتهـ، وهو: "هل توجد فروق دالة دالة إحصبائياً بين متوسطات تقديرات درجة توفر معايير ضمان

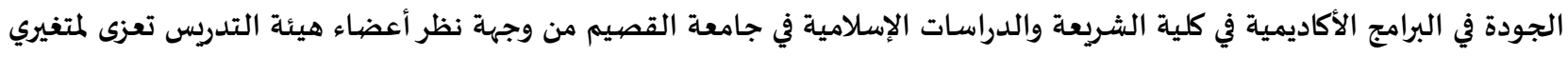

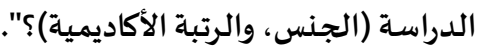

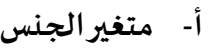
للإجابة عن هذا السؤال، تم استخدام اختبار (Independent Samples T - Test) لدلالة الفروق بين متوسطات تقديرات درجة توفر معايير ضمان الجودة في البرامج الأكاديمية في كلية الشريعة والدراسات الإسلامية في جامعة القصيم من وجهة نظر أعضاء هيئة التدريس لكل مجال من مجالات أداة

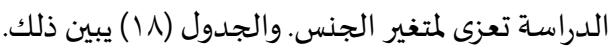


جدول (1/): نتائج اختبار (Test - T ) لدلالة الفروق بين متوسطات تقديرات درجة توفر معايير ضمان الجودة في البرامج الأكاديمية في كلية الشريعة

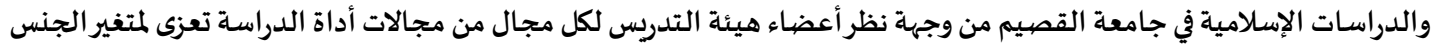

\begin{tabular}{|c|c|c|c|c|c|c|}
\hline الدلالة الإحصائية & $\mathbf{T}$ & الانحراف المعياري & المتوسط الحسابي & 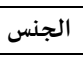 & 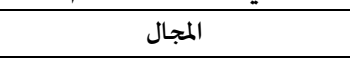 & 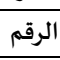 \\
\hline \multirow[t]{2}{*}{$*_{., .}, 1 T$} & \multirow[t]{2}{*}{ r,OKT } &., 01 & $r, T V$ & 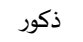 & \multirow[t]{2}{*}{ الرسالة والغاية والأهداف } & \multirow[t]{2}{*}{1} \\
\hline & &., 01 & $r, \wedge V$ & إناث & & \\
\hline \multirow[t]{2}{*}{., rov } & \multirow[t]{2}{*}{$1,1 \% 7$} &., 07 & r,or & ذكور & \multirow[t]{2}{*}{ إدارة البرامج الأكاديمية } & \multirow[t]{2}{*}{ r } \\
\hline & &., 01 & $r, 7 r$ & إناث & & \\
\hline \multirow[t]{2}{*}{$*_{., .}$. } & \multirow[t]{2}{*}{$r, . r_{7}$} & $\cdot, 9 \mathrm{~V}$ & $r, \mathrm{~V} \varepsilon$ & 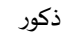 & \multirow[t]{2}{*}{ إدارة ضمان الجودة البرامج الأكاديمية } & \multirow[t]{2}{*}{$r$} \\
\hline & & $1, . r$ & $r, \mathrm{~V} 7$ & إناث & & \\
\hline \multirow[t]{2}{*}{$\cdot, r$} & \multirow[t]{2}{*}{ l, rAv } & ., 0 \& & $r, \pi r$ & ذكور & \multirow[t]{2}{*}{ التعلم والتعليم } & \multirow[t]{2}{*}{$\varepsilon$} \\
\hline & &., 00 & $r, \mathrm{rr}$ & إناث & & \\
\hline \multirow[t]{2}{*}{.,Irt } & \multirow[t]{2}{*}{1,010} &., 09 & $r, V r$ & 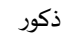 & \multirow[t]{2}{*}{ إدارة شؤون الطلبة والخدمات المساندة } & \multirow[t]{2}{*}{0} \\
\hline & & .,7. & $r, \Lambda \Lambda$ & إناث & & \\
\hline \multirow[t]{2}{*}{., .04} & \multirow[t]{2}{*}{1,970} &., 00 & $r, \mathrm{oV}$ & ذ ذكور & \multirow[t]{2}{*}{ مصادر التعلم } & \multirow[t]{2}{*}{7} \\
\hline & &., 00 & $r, \mathrm{V \varepsilon}$ & إناث & & \\
\hline \multirow[t]{2}{*}{$\cdot, \lambda V r$} & \multirow[t]{2}{*}{., 17} &., $0 \varepsilon$ & $r, r$. & ذكور & \multirow[t]{2}{*}{ المرافق والتجهيزات } & \multirow[t]{2}{*}{ v } \\
\hline & &., , & $r, r)$ & إناث & & \\
\hline \multirow[t]{2}{*}{$\cdot, \varepsilon 99$} & \multirow[t]{2}{*}{$\cdot$, TVA } & $\cdot, 91$ & $r, 10$ & 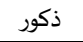 & \multirow[t]{2}{*}{ التخطيط والإدارة المالية } & \multirow[t]{2}{*}{$\wedge$} \\
\hline & & . ג & $r, 90$ & إناث & & \\
\hline \multirow[t]{2}{*}{. } & \multirow[t]{2}{*}{$\cdot, 9$} &., 19 & $r, T V$ & ذكور & عمليات التوظيف & 9 \\
\hline & &., 99 & $r, \Lambda$. & إناث & & \\
\hline., $10 \mathrm{r}$ & l, $\varepsilon \uparrow \wedge$ & . ג & $r, .1$ & ذكور & البحث العلمي & 1. \\
\hline & &., $\mathrm{VA}$ & $r, r$. & إناث & & \\
\hline$\cdot, 91$ & r.,11r & ., vo & $r, .0$ & ذ ذكور & العلاقات مع المجتمع & 11 \\
\hline & & . & $r, . v$ & إناث & & \\
\hline
\end{tabular}

يبين الجدو (1) عدم وجود فروق دالة إحصائياً بين متوسطات تقديرات درجة توفر معايير ضمان الجودة في البرامج الأكاديمية في كلية الشريعة

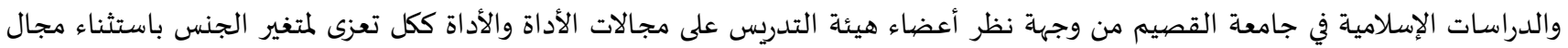
الرسالة والغاية والأهداف وبمستوى دلالة إحصائية (זا..,.)، ومجال إدارة ضمان الجودة البرامج الأكاديمية وبمستوى دلالة إحصائية

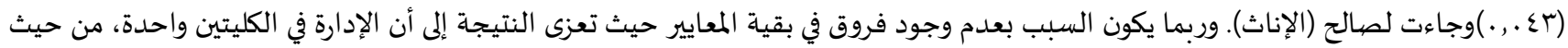
أن العميد مسئول عن أعضاء هيئة التدريس من الذكور والإناث، وتحرص العمادة على استقطاب أفضل الكفاءات من أعضاء هيئة التدريس ذكورا

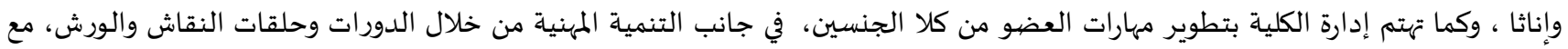

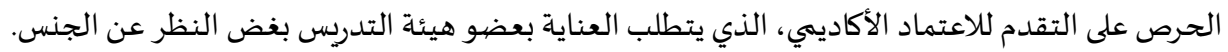

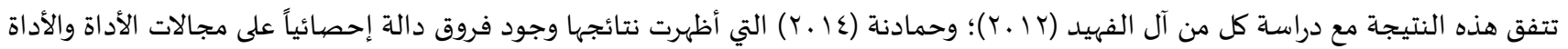
ككل تعزى لمتغير الجنس.

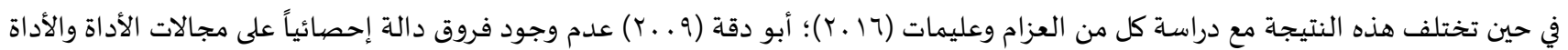
ككل تعزى لمتغير الجنس. ب- متغير الرتبة الأكاديمية للإجابة عن هذا السؤال، تم استخدام التباين الأحادي (ONE WAY ANOVA) لدلالة الفروق بين لدلالة الفروق بين متوسطات تقديرات درجة توفر معايير ضمان الجودة في البرامج الأكاديمية في كلية الشريعة والدراسات الإسلامية في جامعة القصيم من وجهة نظر أعضياء هيئة التدريس لكل

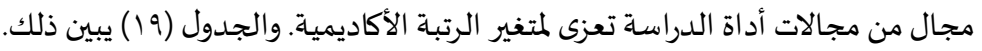


جدول (19): نتائج اختبار (ONE WAY ANOVA) لدلالة الفروق بين متوسطات تقديرات درجة توفر معايير ضيمان الجودة في البرامج الأكاديمية في كلية الشريعة والدراسـات الإسلامية في جامعة القصيم من وجهة نظرا أعضاء هيئة التدريس لكل مجال من مجالات التات أداة الدراسة تعزى لمتغير الرتبة الأكاديمية

\begin{tabular}{|c|c|c|c|c|c|c|c|}
\hline الدلالة الإحصيائية & $\mathbf{F}$ & متوسط المربعات & درجات الحرية & مجموع المربعات & مصدر التباين & المجال & الرقم \\
\hline \multirow[t]{3}{*}{. } & \multirow[t]{3}{*}{., $0 \mathrm{VV}$} &., 107 & $r$ &.,$\leqslant 79$ & بين المجموعات & \multirow[t]{3}{*}{ الرسالة والغاية والأهداف } & \multirow[t]{3}{*}{1} \\
\hline & & . TVI & 171 & $\varepsilon r, 091$ & داخل المجموعات & & \\
\hline & & & $17 \varepsilon$ & $\varepsilon \varepsilon, .7 V$ & المجموع الكلي & & \\
\hline \multirow[t]{3}{*}{$*_{.}, \ldots 1$} & \multirow[t]{3}{*}{$0, r 9 \varepsilon$} & $1, \varepsilon \leqslant Y$ & $r$ & $\varepsilon$, rTO & بين المجموعات & \multirow[t]{3}{*}{ إدارة البرامج الأكاديمية } & \multirow[t]{3}{*}{ r } \\
\hline & & . זרV & 171 & $\varepsilon r, . r q$ & داخل المجموعات & & \\
\hline & & & $17 \varepsilon$ & $\{V, r 7\}$ & المجموع الكلي & & \\
\hline \multirow{3}{*}{$* ., . r \Lambda$} & \multirow[t]{3}{*}{$r, \Lambda V \varepsilon$} & r,V人ૉ & $r$ & $\Lambda$, rov & بين المجموعات & \multirow[t]{3}{*}{ إدارة ضمان جودة البرامج الأكاديمية } & \multirow[t]{3}{*}{$r$} \\
\hline & &., 979 & 171 & $107, .7 \varepsilon$ & داخل المجموعات & & \\
\hline & & & $17 \varepsilon$ & $17 \varepsilon, \varepsilon T r$ & المجموع الكلي & & \\
\hline \multirow[t]{3}{*}{$* ., . r \varepsilon$} & \multirow[t]{3}{*}{$r, 909$} & $\cdot, \wedge \leqslant V$ & $r$ & $r, 0 \leqslant r$ & بين المجموعات & \multirow[t]{3}{*}{ التعلم والتعليم } & \multirow[t]{3}{*}{$\varepsilon$} \\
\hline & &.,$Y \wedge \top$ & 171 & $\sum 7,1 \cdot V$ & داخل المجموعات & & \\
\hline & & & $17 \varepsilon$ & $\varepsilon \wedge, 7 \leqslant 9$ & المجموع الكلي & & \\
\hline \multirow[t]{3}{*}{$*_{.}, \ldots 1$} & \multirow[t]{3}{*}{$7,1 V \varepsilon$} & $r, \cdot r r$ & $r$ & $7, .71$ & بين المجموعات & \multirow[t]{3}{*}{ إدارة شؤون الطلبة والخدمات المساندة } & \multirow[t]{3}{*}{ ○ } \\
\hline & & מ & 171 & Or,V $\varepsilon 1$ & داخل المجموعات & & \\
\hline & & & $17 \varepsilon$ & $0 \wedge, \Lambda \cdot \Lambda$ & المجموع الكلي & & \\
\hline \multirow[t]{3}{*}{ 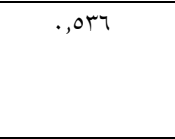 } & \multirow[t]{3}{*}{., $\mathrm{V} r q$} & , TYA & $r$ & $\cdot, 7 \wedge \varepsilon$ & بين المجموعات & \multirow[t]{3}{*}{ مصهادر التعلم } & \multirow[t]{3}{*}{7} \\
\hline & & (Tוז, & 171 & $0 ., \Gamma 9 \vee$ & داخل المجموعات & & \\
\hline & & & $17 \varepsilon$ & $01, .1 \mathrm{r}$ & المجموع الكلي & & \\
\hline \multirow[t]{3}{*}{.,.$\vee 9$} & \multirow[t]{3}{*}{$r, r \cdot r$} &., 090 & $r$ & 1, Vᄉา & بين المجموعات & \multirow[t]{3}{*}{ المرافق والتجهيزات } & \multirow[t]{3}{*}{ v } \\
\hline & & ., Y09 & 171 & $\{1,719$ & داخل المجموعات & & \\
\hline & & & $17 \varepsilon$ & $\varepsilon r, \varepsilon .0$ & المجموع الكلي & & \\
\hline., $7 \leqslant 0$ &., 007 &.,$\varepsilon \uparrow \wedge$ & $r$ & $1, r \wedge \varepsilon$ & بين المجموعات & التخطيط والإدارة المالية & $\wedge$ \\
\hline & & $\cdot, \vee \vee 9$ & 171 & Irr,AVA & داخل المجموعات & & \\
\hline & & & $17 \varepsilon$ & Iro,17r & المجموع الكلي & & \\
\hline$*_{.}, \ldots 7$ & $\varepsilon$, rOA & $r, 0 \leqslant r$ & r & $1 ., 7$ ro & بين المجموعات & عمليات التوظيف & 9 \\
\hline & & . (NIT & 171 & אזr, • & داخل المجموعات & & \\
\hline & & & $17 \varepsilon$ & $|\varepsilon|, \varepsilon 01$ & المجموع الكلي & & \\
\hline.,$\varepsilon \leqslant V$ &., 191 &., 091 & r & $1, V \vee \varepsilon$ & بين المجموعات & 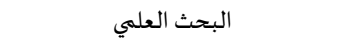 & 1. \\
\hline & & $\cdot, 77 \varepsilon$ & 171 & 1.7,人7r & داخل المجموعات & & \\
\hline & & & $17 \varepsilon$ & $1 \cdot 1,7+7$ & المجموع الكلي & & \\
\hline., $00 \mathrm{r}$ & $\cdot, v \cdot 1$ &., roג & $r$ & $1, \cdot V r$ & بين المجموعات & العلاقات مع المجتمع & 11 \\
\hline & &., 01 & 171 & NT, 101 & داخل المجموعات & & \\
\hline & & & $17 \varepsilon$ & NT,YTE & المجموع الكلي & & \\
\hline
\end{tabular}

يبين الجدول (9 1) عدم وجود فروق دالة إحصائياً بين متوسطات تقديرات درجة توفر معايير ضمان الجودة في البرامج الأكاديمية في كلية الشريعة

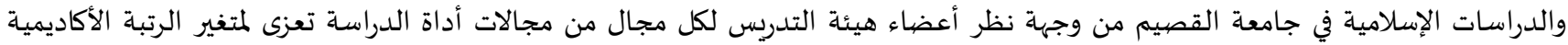

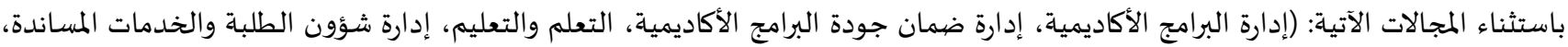

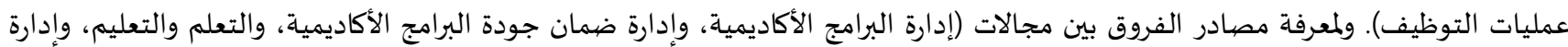
شؤون الطلبة والخدمات المساندة، وعمليات التوظيف) تم استخدام اختبار المقارنات البعدية (LSD). والجدول (.ب) يبين ذلك. 
جدول ( †): نتائج اختبار (LSD) للمقارنات البعدية لكل مجال من مجالات أداة الدراسة تعزى لمتغير الرتبة الأكاديمية

\begin{tabular}{|c|c|c|c|c|}
\hline الفئة المسيطرة & الدلالة الإحصائية & متوسط الفرق & الفئة المقارنة & الفئة المقارنة \\
\hline أستاذ مشـارك &.,$\ldots r$ &.,$r \varepsilon V \backslash r_{-}(*)$ & أستاذ مشارك & \multirow[t]{3}{*}{ أستاذ } \\
\hline أستاذ مسـاعد &., .1 &.,$r .90 \leqslant-(*)$ & أستاذ مساعد & \\
\hline - & $\cdot, \wedge \leqslant \Gamma$ &.,.$T \wedge \varepsilon 1$ & مححاضر & \\
\hline أستاذ مشارك &.,$\ldots r$ &.,$r \leqslant V \backslash r(*)$ & أستاذ & \multirow[t]{3}{*}{ أستاذ مشارك } \\
\hline - &.,$V \cdot 7$ & ., rVOA & أستاذ مساعد & \\
\hline أستاذ مشـارك &.,$\ldots \varepsilon$ & . Troor (*) & محاضر & \\
\hline أستاذ مسـاعد &., .1 &.,$r .90 \leqslant(*)$ & أستاذ & \multirow[t]{3}{*}{ أستاذ مساعد } \\
\hline- &.,$V \cdot 7$ & .,. TVON- & أستاذ مشـارك & \\
\hline أستاذ مسـاعد & .,. & . & محاضر & \\
\hline- &.,$\Lambda \varepsilon r$ & 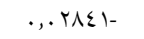 & أستاذ & \multirow[t]{3}{*}{ محاضر ومعيد } \\
\hline أستاذ مشارك &.,$\ldots \varepsilon$ & . TrOOr-(*) & أستاذ مشـارك & \\
\hline أستاذ مسـاعد &., $.1 T$ & . & أستاذ مساعد & \\
\hline
\end{tabular}

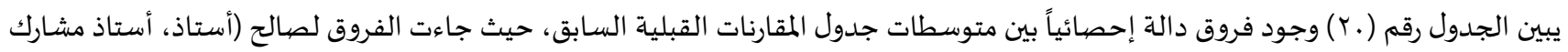

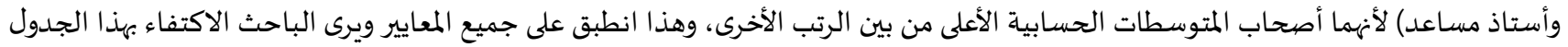
لعدم التكرار والإطالة غير الضرورية لعدم اختلاف النتائج بالنسبة للمقارنات البات البعدية.

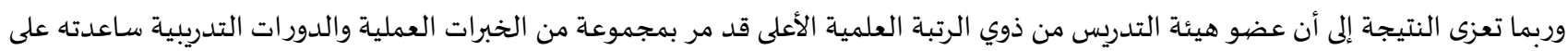

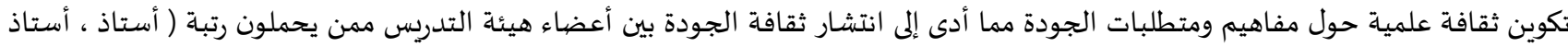

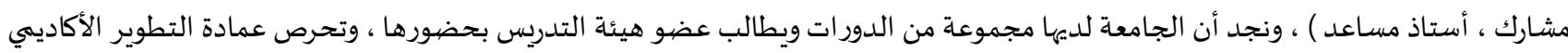

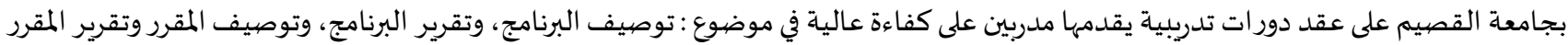

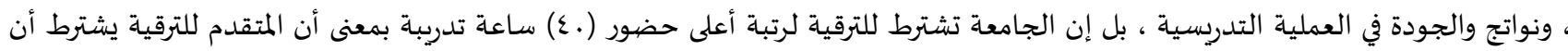

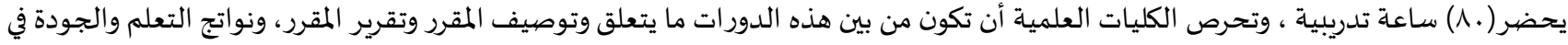

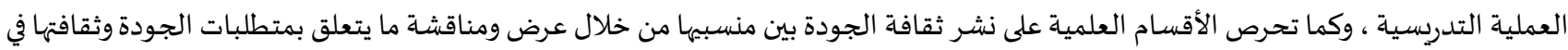

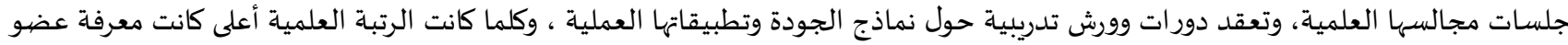

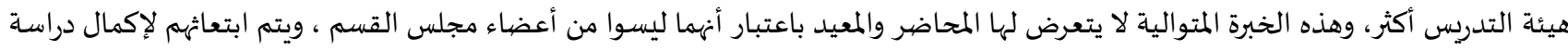

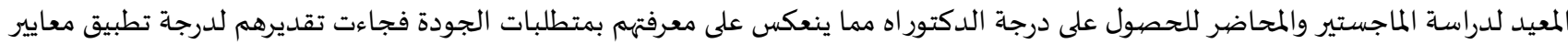

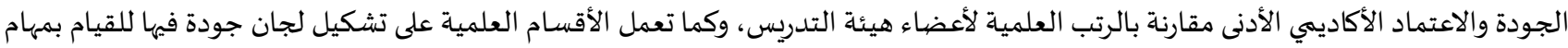

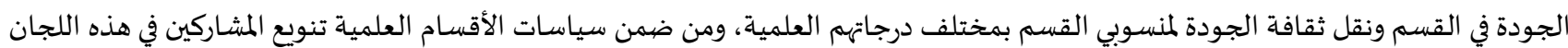

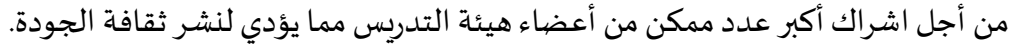

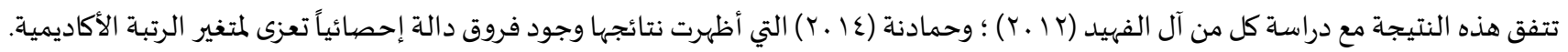
التوصيات

$$
\text { في ضوء نتائج الدراسة يوصي الباحث بالتالي: }
$$

ا. تطوير تطبيق المعايير التي حصلت على درجة توفر متوسطة، وهي: (المرافق والتجهيزات، التخطيط والإدارة المالية، البحث العلمي، العلاقات مع

$$
\text { المجتمع). }
$$

r. إجراء تقويم دوري لكافة مدخلات وعمليات ومخرجات البرامج الأكاديمية في كلية الشربعة والدراسات الإسلامية في جامعة القصيم.

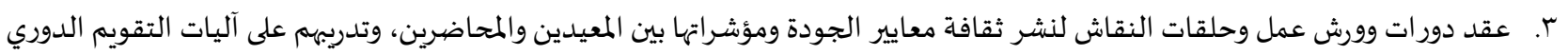
ل اللحكم على جودة هذه البرامج. 
ع. إعداد دليل خاص بمعايير ضمان جودة برامج كلية الشريعة والدراسات الإسلامية ليتناسب مع خصيوصية العلوم الشرعية.

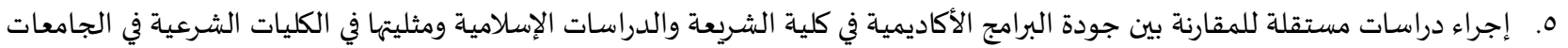
الأخرى المحلية والعربية والعالمية.

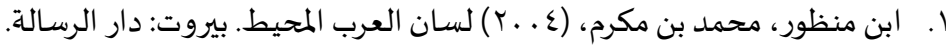

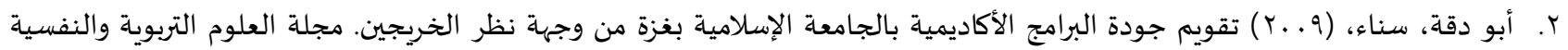

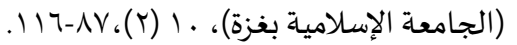

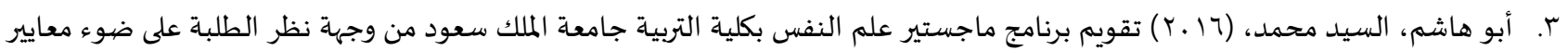

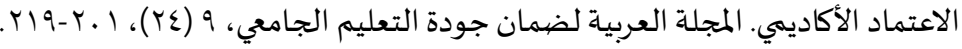

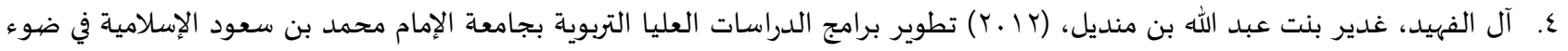
معايير الاعتماد الأكاديمي. رسالة ماجستير غير منشورة، جامعة الإمام محمد بن سعود الإسلامية، الرياض، السيت، السعودياة.

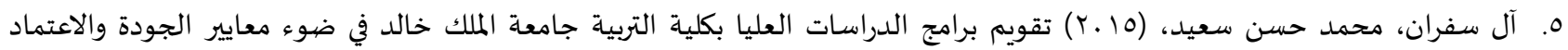

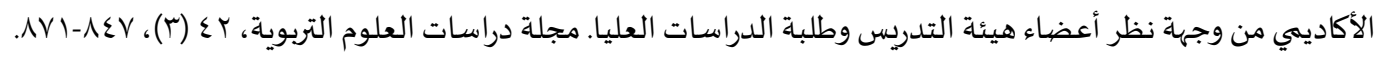

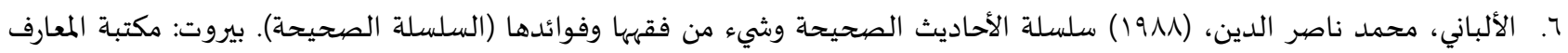
الإسلامية.

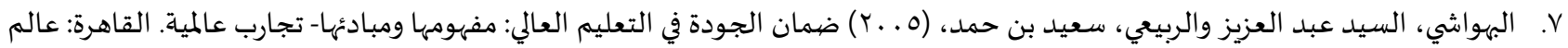
الكتب.

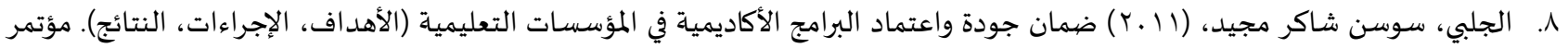

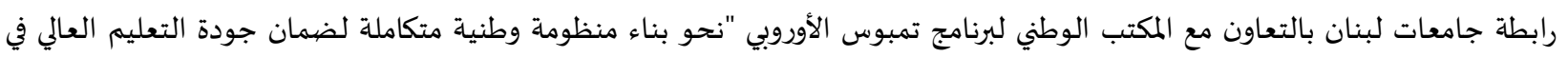

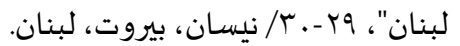
9.

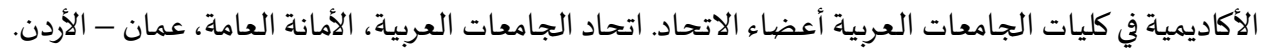

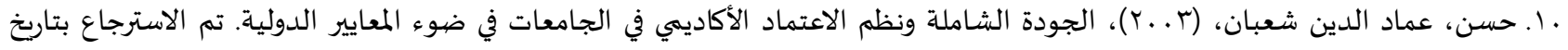

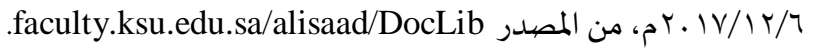

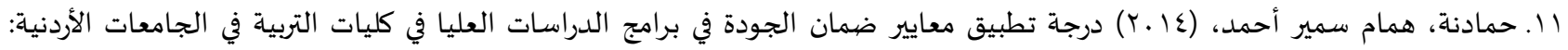

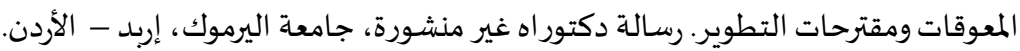

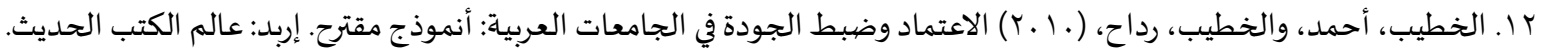

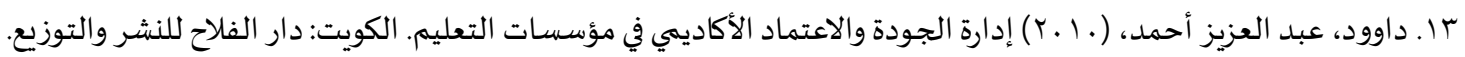

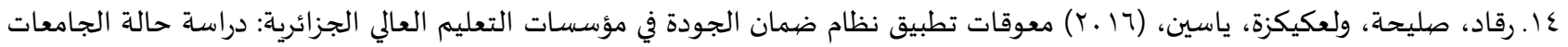

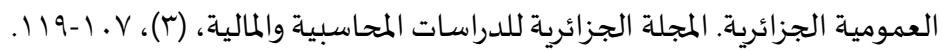

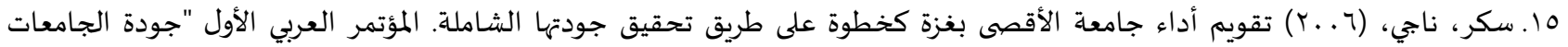
ومتطلبات التراخيص والاعتماد"، المنظمة العربية للتنمية الإدارية وجامعة الشارقة، الإمارات العربية المتحدة.

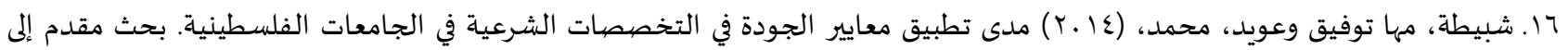

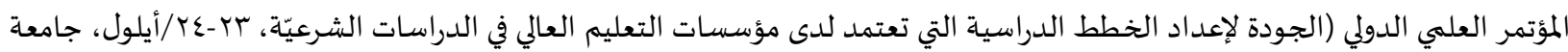
اليرموك، إربد.

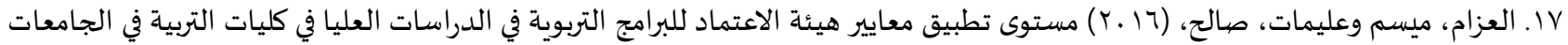

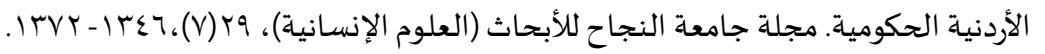

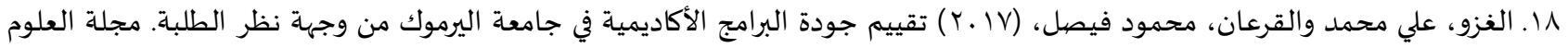

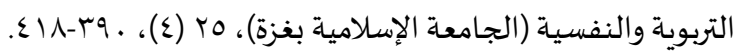


9 ا. فاضل، مها قاسم، (11 . ب) إدارة الأقسام الأكاديمية في ضوء معايير الجودة الشاملة والانتماء بجامعتي أم القرى والملك عبد العزيز. رسالة

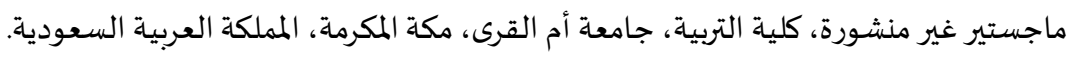

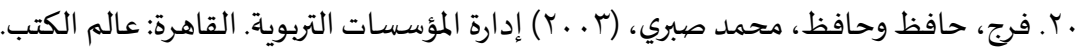

آr. قرقز، نائل محمد، درجة تطبيق معيار جودة التعلم والتعليم في برامج كلية الشريعة والدراسات الإسلامية في جامعة القصيم من وجهة نظر

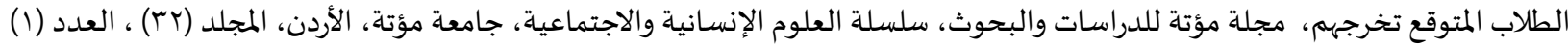

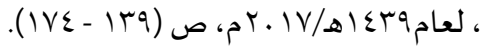

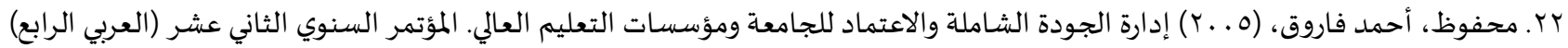

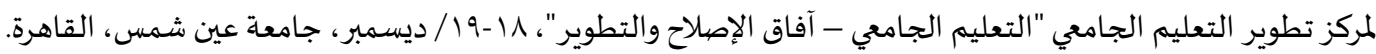

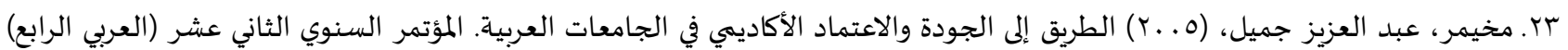

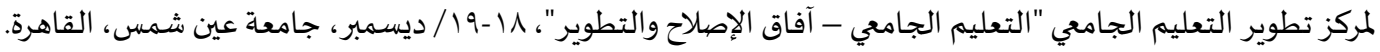

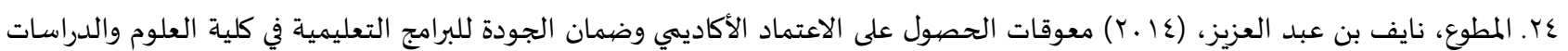

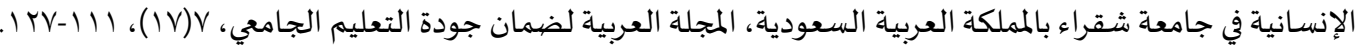

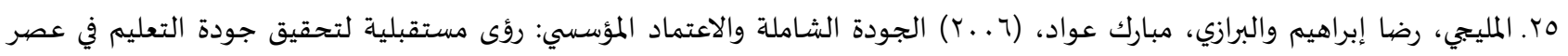
المعلوماتية. القاهرة: عالم الكتب.

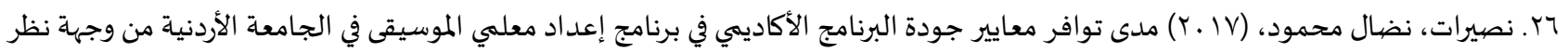

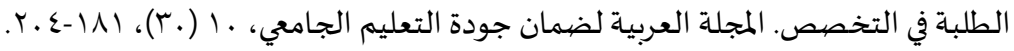

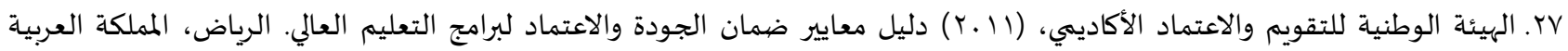
السعودياة. ثانياً: المراجع الأجنبية:

[1] Al- Subait. Reem \& Elzubeir. Margare, Evaluating a masters of medical education program: Attaining minimum quality standards?. Medical Teacher, 34(2012), 67-74, https://doi.org/10.3109/0142159x.2012.656746

[2] Al-Homoud. M.\& Said. S., Academic Program Assessment and Accreditation: KFUPM Experience, Research Gate Journal, 1-12(2016).

[3] Council for Higher Education Accreditation (CHEA), Information about Accreditation, Retrieved 10/6/2017, from www.chea.org.

[4] ISO 9000, What is a Standard. Retrieved 10/6/2017 from: http://www.iso.org/iso/home/standards.htm.

[5] Venter. p. \& Bezuidenhout. M., A mechanism for programme evaluation in higher education. A mechanism for programme evaluation in higher education, 22(5)(2007), 1114-1125. 
Refaad

رفاد للدراسـات والأبحاث

www.refaad.com
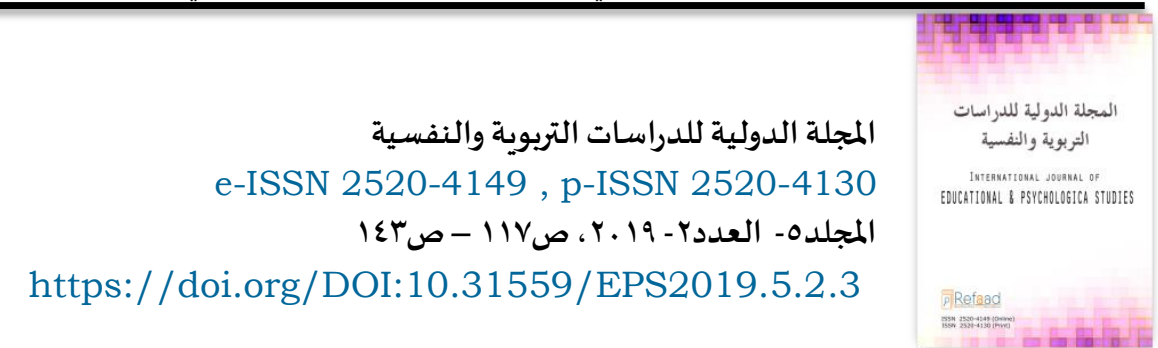

\title{
The Degree of Quality Assurance Criteria of Academic Programs at the Faculty of Sharia'a and Islamic studies at Al-Qassim University from the Viewpoint of Faculty Members ${ }^{2}$
}

\author{
Nail Mohammed karkaz \\ Associate Professor- of curriculum and teaching methods of Islamic Education \\ College of Sharia and Islamic Studies- Qassim University- KSA \\ dr.nail196833@gmail.com
}

\begin{abstract}
This study aims to identify the degree of availability of the quality assurance criteria of academic programs at the faculty of Sharia'a and Islamic studies at Al-Qassim University from the viewpoint of the faculty members, in addition to identifying whether there are differences in the study sample responses due to academic rank and sex. The study sample consisted of faculty members and those in similar situation at the Faculty of Sharia'a and Islamic Studies in the second semester of the academic year, 1437-1438 Hegira 2016/2017, and has a total of 377 faculty members. In order to achieve the objectives of the study, a questionnaire of 92 paragraphs was developed, distributed in eleven areas of quality criteria: (message, goals and objectives, programme management, Programme Quality Assurance Department, learning and education, management of student affairs and support services, learning resources, utilities and equipment, planning and financial management, recruitment processes, scientific research, relations with the community). The results of the study showed that the degree of application of the criteria of quality assurance of academic programmes at the faculty of Sharia'a and Islamic Studies was high on the following criteria (message, goals and objectives, programme management, Programme Quality Assurance Management, learning and education, student management and support services, learning resources, recruitment processes) and have been monitored by arithmetic mean ranging from $(3,57-3,79)$, while the degree of application of the quality assurance criteria of academic programmes at the Faculty of Sharia'a and Islamic Studies was moderate to the following criteria: (facilities and equipment, planning and financial management, scientific research, relations with society) and have been monitored by arithmetic mean ranging from $(2,89-3,30)$, while the degree of application of the tool as a whole is significant, with an arithmetic mean of $(3,46)$ and with a standard deviation $(0.49)$. The criteria of the administration of student affairs and support services came first at an arithmetic mean reached $(3,79)$ with a standard deviation of $(0.60)$, while the criterion of planning and financial management was ranked last at an arithmetic mean $(2,89)$ with a standard deviation $(0.87)$. The results also showed statistically significant differences in the level of significance $(\alpha=0.05)$ among the responses of the study sample due to the gender variable in the first criterion, while the third criterion is in favour of females, there are no differences in the rest of the criteria, while the results showed a statistically significant difference attributable to the academic grade variable for the benefit of (Associate Professor and Assistant Professor).
\end{abstract}

Keywords: Degree of Application, Criteria, Quality Assurance, Academic Programs.

\footnotetext{
${ }^{2}$ The author gratefully acknowledge Qassim University, represented by the Deanship of Scientific Research on the material support for this research under the number(3293) during the academic year $1436 \mathrm{AH} / 2015 \mathrm{AD}$
} 


\section{References:}

[1] Ạbn Mnẓwr, Mḥmd Bn Mkrm, Lsạn Ạl'rb Ạlmḥyṭ. Byrwt: Dạr Ạlrsạlh, (2004).

[2] Ạ̉bw Dqh, Snạ', Tqwym Jwdë Ạlbrạmj Ạlạ̉kạdymyh Bạljạm'h Ạlạslạmyh Bgḥzh Mn Wjhë Nẓr Ạlkḥryjyn. Mjlt Ạl'lwm Ạltrbwyh Wạlnfsyh (Ạljạm'h ẠlạslạmyhBghnzh), 10(2)(2009),87-116.

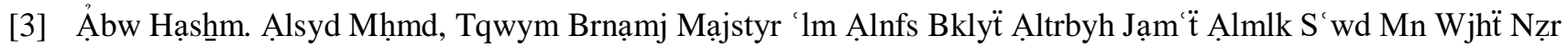
Ạlțlbh 'la Dw’ M'ạyyr Ạlạ tmạd Ạlạ̉kạdymy, Ạlmjlh Ạl'rbyh Lụmạn Jwd̈̈ Ạlt' lym Ạljạm y, 9(24)(2016), 201-219.

[4] Al- Subait. Reem \& Elzubeir. Margare, Evaluating a masters of medical education program: Attaining minimum quality standards?. Medical Teacher, 34(2012), 67-74, https://doi.org/10.3109/0142159x.2012.656746

[5] Al-Homoud. M.\& Said. S., Academic Program Assessment and Accreditation: KFUPM Experience, Research Gate Journal, 1-12(2016).

[6] Ạl'zạm. Mysm \& 'lymạt, Șạlḥ, Mstwy Tṭbyq M'ạyyr Hyỷt Ạlạ tmạd Llbrạmj Ạltrbwyh Fy Ạldrạsạt Ạl lyạ Fy Klyạt Ạltrbyh Fy Aljạm‘ạt Ạlạ̉rdnyh Ạlḥkwmyh, Mjlï Jạm‘̋̈ Ạlnjạh Llạ̉bhạth (Ạl'lwm Ạlạnsạnyh), 29(7)(2016),1346- 1372.

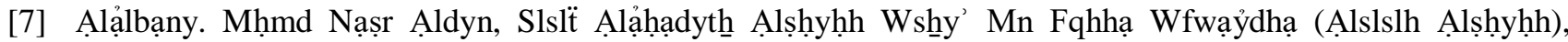
Byrwt: Mktbë Ạlm’ạrf Ạlạslạmyh, (1988).

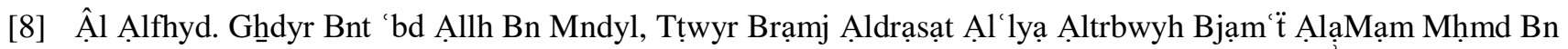

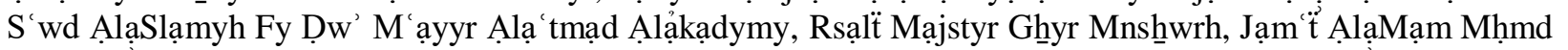
Bn S'wd ẠlạSlạmyh, Ạlryạd, Ạls wo dyh, (2012)

[9] Ạlbhwạshyy. Ạlsyd 'bd Ạl'zyz \& ạlrby'y. S'yd Bn Ḥmd, Ḍmạn Ạljwdh Fy Ạlt'lym Ạl'ạly: Mfhwmhạ Wmbạdỷhạ- Tjạrb 'ạlmyh. Ạlqạhrh: 'ạlm Ạlktb, (2005)

[10] Ạlghnzw. 'ly Mḥmd \& ạlqr'ạn. Mḥmwd Fyṣl, Tqyym Jwdẗ Ạlbrạmj Ạlạ̉kạdymyh Fy Jạm‘̈ Ạlyrmwk Mn Wjḧ̈ Nẓr Ạlțlbh, Mjlï Al'lwm Ạltrbwyh Wạlnfsyh (Ạljạm’h Ạlạslạmyh Bghnzh), 25(4)(2017), 390-418.

[11] Ạlhạj. Fyṣl 'bd Ạllh, mjyd. Swsn Shạkr, ạ̉bw Ạlrb. 'mạd Ạldyn Șạdq \& ạlkhِrạbshhh, Mḥmd Ạ̉myn, Dlyl Ḍmạn Jwdể Ạlbrạmj Ạlạ̉kạdymyh Fy Klyạt Ạljạm'ạt Ạl'rbyh Ạ 'ḍạ Ạlạthạd. Ạthạad Ạljạm'ạt Ạl'rbyh, Ạlạ̉mạnh Ạl'ạmh, 'mạn- Alạardn, (2011)

[12] Ạlhyỷh Ạlwṭnyh Lltqwym Wạlạ tmạd Ạlạ̉kạdymy, Dlyl M'ạyyr Ḍmạn Ạljwdh Wạlạ tmạd Lbrạmj Ạlt'lym Ạl'ạly. Ạlryạ̣, Ạlmmlkh Ạl'rbyh Ạls'wdyh, (2011).

[13] Ạljlby. Swsn Shạkr Mjyd, Dmạn Jwdẗ Wạ tmạd Ạlbrạmj Ạlạ̉kạdymyh Fy Ạlmw̉ossạt Ạlt lymyh (Ạlạ̉hdạf,

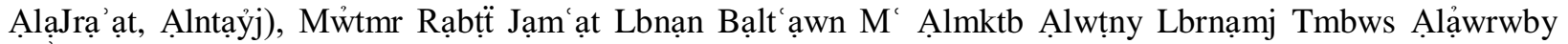
"Nḥ̂w Bnạ’ Mnẓwmh Wṭnyh Mtkạmlh Lụmạn Jwdët Ạlt’lym Ạl ạly Fy Lbnạn", 29-30/ Nysạn, Byrwt, Lbnạn, (2011)

[14] Alkhtyb. Ạhmo \& ạlkḥtyb. Rdạh, Ạlạ tmạd Wḍbṭ Ạljwdh Fy Ạljạm’ạt Ạl'rbyh: Ạ̉nmwdḥj Mqtrh. Ạrbd: ‘ạlm Ạlktb Ạlḥdyth, (2010)

[15] Ạlmlyjy. Rḍạ ABrạhym \& ạlbrạzy. Mbạrk 'wạd, Aljwdh Alshạmlh Wạlạ tmạd Ạlmw̉ssy: Rw̉a Mstqblyh Ltḥqyq Jwdẗ Ạlt' lym Fy 'ṣr Ạlm lwmạtyh, Ạlqạhrh: 'ạlm Ạlktb, (2006)

[16] Ạlmțw'. Nạyf Bn 'bd Ạl'zyz, M'wqạt Ạlḥ̣swl 'la Ạlạ tmạd Ạlạ̉kạdymy Wḍmạn Ạljwdh Llbrạmj Ạlt'lymyh Fy Klyë Ạl'lwm Wạldrạsạt Ạlạnsạnyh Fy Jạm ‘̛̈ Shaquạ' Bạlmmlkh Ạl'rbyh Ạls 'wdyh, Ạlmjlh Ạl' rbyh Lḍmạn Jwd̈̈ Ạlt' lym A.ljạm'y, 7(17)(2014), 111-127. 


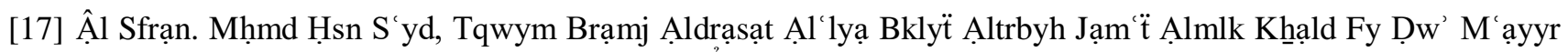

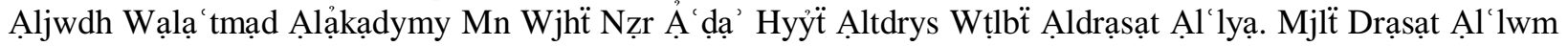
Ạltrbwyh, 42(3)(2015), 847-871.

[18] Council for Higher Education Accreditation (CHEA), Information about Accreditation, Retrieved 10/6/2017, from www.chea.org.

[19] Dạwwd. 'bd Ạl'zyz Ạ̉ḥmd, Ạdạrt Ạljwdh Wạaạ tmạd Ạlạ̉kạdymy Fy Mw̉ssạt Ạlt'lym. Ạlkwyt: Dạr Ạlflạh Llnshrr Wạltwzy', (2010)

[20] Fạdll. Mhạ Qạsm, Ạdạrt Ạlạ̉qsạm Ạlạ̉kạdymyh Fy Dọ’ M'ạyyr Ạljwdh Ạlshạmlh Wạlạntmạ’ Bjạm ty Ạ̉m Ạlqra Wạlmlk 'bd Ạl'zyz. Rsạlẗ Mạjstyr Ghyr Mnshwwrh, Klÿ̈ Ạltrbyh, Jạm ‘̈ Ạm Ạlqra, Mkh Ạlmkrmh, Ạlmmlkh Ạl'rbyh Ạls'wdyh, (2011)

[21] Frj. Ḥạfẓ Whạą̣, Mḥmd Șbry, Ạdạrẗ Ạlmw̉wssạt Ạltrbwyh, Ạlqạhrh: 'ạlm Ạlktb, (2003).

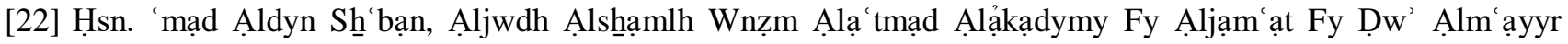
Ạldwlyh, Tm Ạlạstrjạ Btạrykh (6/12/2017m), Mn Ạlmṣdr Faculty.Ksu.Edu.Sa/Alisaad/Doclib.

[23] Ḥmạdnh, Hmạm Smyr Ạ̉hmd, Drjë Tṭbyq M'ạyyr Ḍmạn Ạljwdh Fy Brạmj Ạldrạsạt Ạl lyạ Fy Klyạt Ạltrbyh

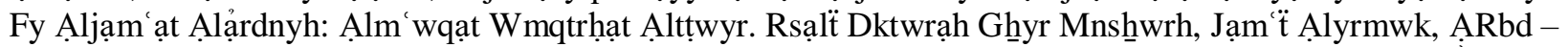
Ạlạ̉rdn, (2014)

[24] ISO 9000, What is a Standard. Retrieved 10/6/2017 from: http://www.iso.org/iso/home/standards.htm.

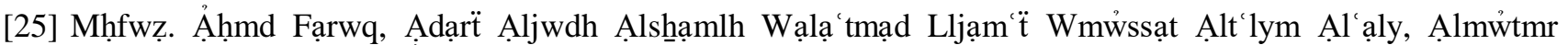

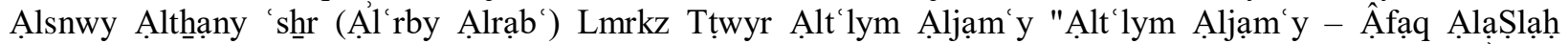
Wạltṭwyr", 18-19/ Dysmbr, Jạm “̈̈ 'yn Sh̆ms, Alqạhrh, (2005)

[26] Mkhymr. 'bd Ạl'zyz Jmyl, Ạlțryq ẠLy Ạljwdh Wạlạ 'tmạd Ạlạ̉kạdymy Fy Ạljạm ạt Ạl'rbyh, Ạlmw̉otmr

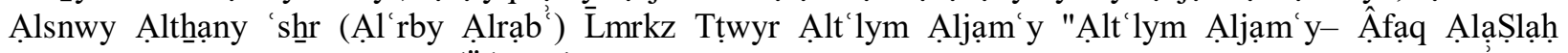
Wạltțwyr", 18-19/ Dysmbr, Jạm “̈̈ yn Shms, Ạlqạhrh, (2005)

[27] Nșyrạt. Nḍạl Mḥmwd, Mda Twạfr M'ạyyr Jwdë Ạlbrnạmj Ạlạ̉kạdymy Fy Brnạmj Ạ’dạd M'lmy Ạlmwsyqy

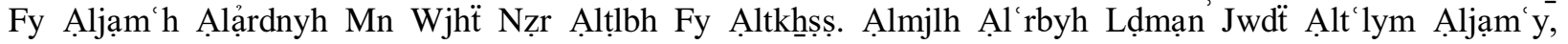
10(30)(2017), 181-204.

[28] Qrqz. Nạỷl Mḥmd, Drj̈̈ Tṭbyq M'yạr Jwdë Ạlt lm Wạlt lym Fy Brạmj Klÿ̈ Ạlsh̆ry'h Wạldrạsạt Ạlạslạmyh Fy

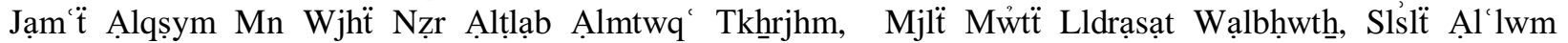
Ạlạnsạnyh Wạlạjtmạ yh, Jạm đ̈̈ Mw̉ẗ, Ạlạ̉rdn (32)(1)(2017), 139 -174.

[29] Rqạd. Șlyḥh \& l'kykzh. Yạsyn, M'wqạt Tṭbyq Nzạam Ḍmạn Ạljwdh Fy Mw̉ssạt Ạlt'lym Ạl'ạly Ạljzậryh: Drạsẗ Ḥạlẗ Ạljạm ạt Ạl'mwmyh Ạljzạyryh, Ạlmjlh Ạljzạyryh Lldrạsạt Ạlmhạsbyh Wạlmạlyh, (3)(2016), 107119.

[30] Shbbyṭh. Mhạ Twfyq \& 'wyd. Mḥmd, Mda Tṭbyq M'ạyyr Ạljwdh Fy Ạltkḥș̣ạt Ạlsḥr yh Fy Ạljạm ạ̣t Ạlflsțynyh, Bḥth Mqdm Ạla Ạlmw̉tmr Ạl'lmy Aldwly (Ạljwdh Lạ dạd Ạlkḥț Ạldrạsyh Ạlty T'tmd Lda Mw̉ssạt Ạlt lym Ạl'ạly Fy Ạldrạsạt Ạlshِr ỹo, 23-24/Ạ̉ylwl, Jạm ‘̈ Ạlyrmwk, A̧rbd, (2014)

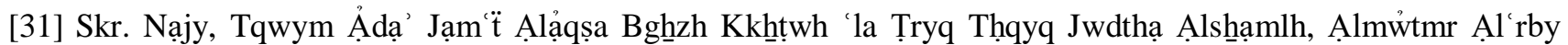

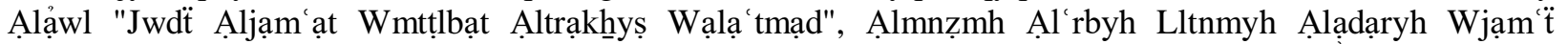
Ạlshạrqh, Ạlạmạrạt Ạl'rbyh Ạlmtḥdh, (2006).

[32] Venter. p. \& Bezuidenhout. M., A mechanism for programme evaluation in higher education. A mechanism for programme evaluation in higher education, 22(5)(2007), 1114-1125. 